\title{
Analysis of Thesis in Turkey between the years 2008- 2020 on Mathematics Literacy
}

\author{
Ayşe Arzu ARI ${ }^{*} \quad$ Barış DEMİ $^{* *}$
}

\begin{abstract}
In recent years, the concept of mathematical literacy has become the main subject of studies on mathematics education. Although there are many graduate theses on mathematics literacy in the current situation, no detailed analysis of them has been found. The purpose of this work, what needs the quantity and quality of the arguments made on mathematics literacy in Turkey meets the criteria, what kind of research is needed to reveal whether the analysis using meta-synthesis method. In the research, the postgraduate theses that were studied on mathematics literacy between 2008 and 2019 and determined by purposeful sampling method were analyzed. The graduate theses examined in the research were obtained as a result of the search made in the database of the Higher Education Council (YÖK) National Thesis Scanning Center. This study is limited to 66 (51 master's and 15 doctoral) postgraduate theses that have been completed on literacy in the field of mathematics education until 2019. The data obtained in the study were analyzed in terms of the university, years and type of theses on mathematics literacy, sample characteristics, targeted purposes, methods used and data collection tools. The obtained data are shown with the help of graphics and tables with frequency. It has been observed that the number of master's and doctoral theses prepared since 2008 has increased, the number of doctoral theses is one-third of the number of master's theses and most of the theses are exited from Uludağ University. In the study, it was determined that most of the theses were carried out to examine mathematical literacy in the context of PISA. It was observed that quantitative screening method was used as the research method most, and questionnaire / scale and tests were used as data collection tools, and studies conducted with students and secondary school level were the majority.
\end{abstract}

Keywords: Mathematical literacy, Content Analysis, Theses

\footnotetext{
* Orcid ID: https://orcid.org/0000-0002-0907-2663, Assist. Prof. Dr., Kocaeli University, Department of Mathematics Education, Turkey, abural@kocaeli.edu.tr

** Orcid ID: https://orcid.org/0000-0001-6997-6413, Lect., Kocaeli University, Department of Business Management, Turkey, barisprof@yahoo.com

Arl, A. A., \& Demir, B. (2020). Analysis of Thesis in Turkey between the years 2008-2020 on Mathematics Literacy, Sakarya University Journal of Education, 10(3), 667-685. doi: https://doi.org/10.19126/suje.796422
} 


\section{INTRODUCTION}

Beyond the acquisition of basic knowledge and skills, learning mathematics includes mathematical thinking, using problem-solving strategies, and seeing that mathematics is an integral part of everyday life (Ministry of National Education - Milli Eğitim Bakanlığı [MEB], 2009). Using mathematical knowledge and skills in daily life is associated with mathematical literacy. In the early 2000s, mathematics educators tried to develop a definition of mathematical literacy that can be used in common in the literature and a mathematical literacy model that can be used in studies of measuring mathematics literacy (Kabael, 2018).

The word literacy in the expression of mathematical literacy has a wider meaning than its counterpart in our language. Being literate in our language means being able to read a written text and write what is said, and its scope is rather superficial. "Mathematical literacy", which is the English for mathematical literacy, has a wider meaning than reading a mathematical text and writing what is said (Altun, 2020). In order to be a mathematical literate, an individual is expected to have two conditions at the same time: The first is to be able to make calculations in order to perform mathematical operations. The other is that he can make applications of mathematics in rapidly increasing different fields (National Council of Teachers of Mathematics [NCTM], 1989). To put it more clearly, a significant amount of mathematical knowledge and skills are required for a mathematical literate individual. This concept includes not only numerical operations and literacy elements, but the ability to be applied to different situations and conditions and to solve related mathematical applications by the individual. The concept of mathematical literacy is made and compared with definitions such as mathematical power, mathematical competence, mathematical skill, spatial and numerical literacy (Çepni, 2016). We can say that mathematical literacy enables a person to be aware and understand the role mathematics plays in the modern world, to be able to make applications related to daily life, to develop skills, to interpret in numerical and spatial thinking, to feel trust, to critical analysis and problem solving in daily life situations (Özgen \& Bindak, 2008).

Mathematical literacy is a way to use and understand mathematics in our individual lives when faced with the need to be constructive, attentive and thoughtful as an individual, and to use individual capacity to identify and understand the role mathematics plays in the world, and to advocate based on a sound cause (İskenderoğlu \& Baki, 2011). In addition, mathematical literacy is defined as recognizing the usage areas of mathematics in daily life and benefiting from mathematics in a positive way to meet the needs and enable the individual to understand the role of mathematics in the world (Education Research and Development Department, Eğitim Araştırma ve Geliştirme Dairesi [EARGED], 2005). Edge (2009) expresses mathematical literacy as understanding mathematics beyond knowledge level.

With the opportunities it provides, mathematics literacy has begun to be investigated in international exams. With this situation, education researchers, media, policy makers 
have been involved in the debates in this field of mathematical literacy (Çepni, 2016). With the PISA (Programme for International Student Assessment) study, which was first implemented in 2000 by OECD (Organisation for Economic Co-operation and Development), mathematics, science and literacy skills of 15-year-old students are evaluated. In each application of the PISA study, which measures the skills of using knowledge and skills in reading, science and mathematics in daily life in 3-year cycles, only one of these areas is emphasized. While making this assessment, it defines the main areas through the concept of literacy. The concept of literacy is expressed as the ability of students to use their knowledge and skills, analyze, make logical inferences and communicate effectively while defining, interpreting and solving the problems they encounter in various situations in basic subject areas (MEB, 2016).

Literacy in the three areas where the assessment is made is defined as follows (Kabael, 2018):

Reading skills: It is the capacity of an individual to understand, use and reflect a written text in order to achieve his goals, develop his knowledge and potential, and participate in society.

Science literacy: It is the ability of an individual to deal with issues and ideas related to science. A science literate individual has the skills to properly explain the facts in the field of science and technology, design and evaluate scientific questions, interpret and scientifically prove the data, and be willing to participate in discourses made within a certain logic.

Mathematical literacy: It is the capacity of students to formulate, use and interpret mathematics in different contexts. This capacity includes the ability to form mathematical reasoning and to use mathematical concepts, processes, rationales, and tools such as describing, explaining, and predicting facts.

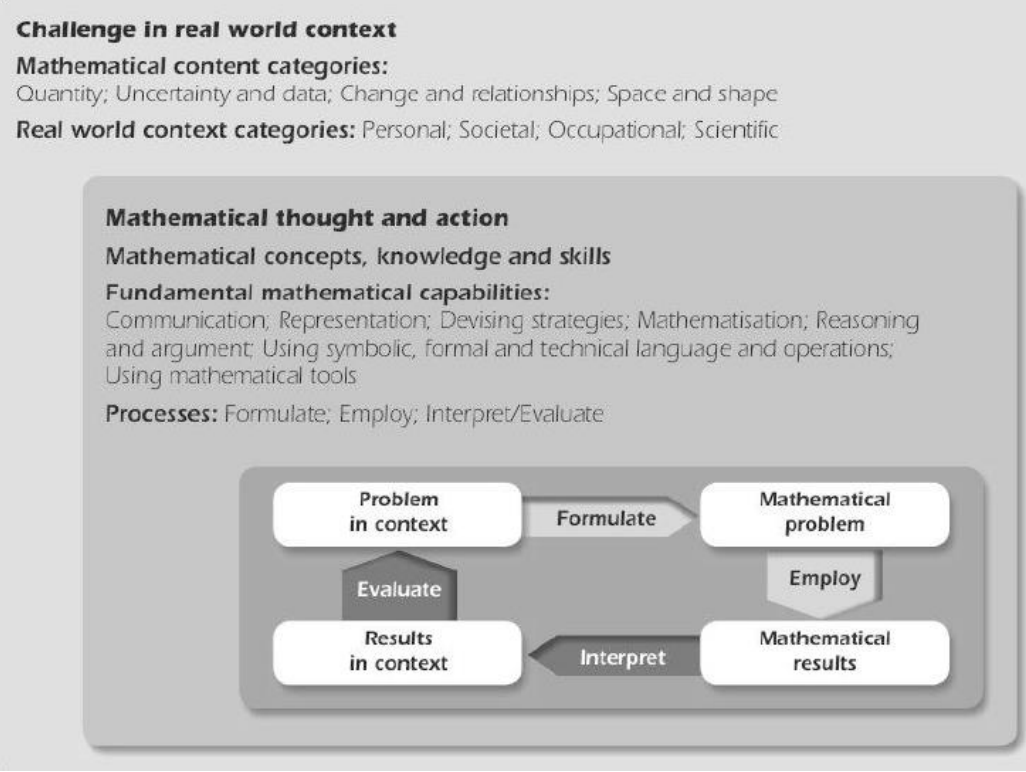


Figure 1. General characteristics of the mathematics literacy assessment framework (MEB, 2016)

The outer rectangular box given in Figure 1 shows the mathematical content categories on which the real-life problem is based and which context of the real life the problem is related to. The mathematical content on which the problem is based constitutes the "content" component of the PISA mathematical literacy framework, while real life categories constitute the "context" component. The inner rectangular box contains the mental processes in the solution process of the problem and the mathematical competencies that should be employed in these processes (Kabael, 2018).

When mathematical literacy studies abroad is examined, it is seen that (Romberg, 2001; Kilpatrick, 2001; De Lange, 2003; Kaiser \& Willander, 2005; Lutzer, 2005; Graven \& Venkatakrishnan, 2006; Julie, 2006; Doyle, 2007; Venkat \& Graven, 2007 ; Solomon, 2008; Mullen, 2009; Ojese, 2011; Hardianti \& Zulkardi, 2019; Umbara \& Suryadi, 2019; Prabawati \& Herman, 2019; Rifandi, Puspita \& Mulyati, 2019; Sanjaya, Putu, Julie, Anggoro and Ruthio, 2019 ; Taufik, Pagiling \& Dadi, 2019; Trapsilasiwi et al., 2019). In our country, the thesis study conducted by Firat (2019), with mathematical literacy in terms of determining the status of Turkey in order to document analysis method has been scanned articles and theses. This research was conducted with additional research questions using only masters and doctoral dissertations content analysis method.

The thesis done on mathematics literacy in mathematics education in Turkey which years and universities, for what purposes, with which methods, on which samples, using which data collection tool is considered important in terms of evaluating it from a critical point of view. In addition, it is thought that it will shed light on researchers who are doing research on mathematical literacy or thinking about doing it.

In this study, to be examined using content analysis of theses regarding made mathematical literacy in Turkey and that kind of approach to this issue in mathematics education and what the needs of quality and quantity in terms of thesis extent that it meets, is intended to demonstrate the need for what kind of research. The following questions were sought in the research.

What is the distribution of theses on mathematical literacy by year and type?

How is the distribution of theses on mathematical literacy among universities?

What are the goals targeted in theses on mathematical literacy?

What are the methods used in theses on mathematical literacy?

What are the preferred sample characteristics in theses on mathematical literacy?

What are the data collection tools used in theses on mathematical literacy?

\section{METHOD}

This section contains the model of the research and information about data collection tools. 


\section{Research Model}

A degradation content analysis method was used in this study aimed at evaluating graduate theses on mathematics literacy in the field of mathematics education. Content analysis; they are research synthesizes that have an important role in disseminating the information researched and shaping future research, policies, practices and public perception. We can break them down into three as meta-analysis, meta synthesis (thematic content analysis) and dethralized content analysis in the most general sense (Çalık and Sözbilir, 2014). Meta-analysis; it is a quantitative application involving statistical processes used for combining, synthesizing and interpreting experimental findings of individual studies carried out at different times and places on the same subject (Wolf, 1986; Durlak, 1995; Çalık and Sözbilir, 2014). Meta-synthesis (thematic content analysis) includes the synthesis and interpretation of research on the same subject from a critical point of view by creating themes or master templates, while dethralized content analysis; systematic studies involving the evaluation of studies on a particular subject and their trends and research results in a defining dimension (Çalık and Sözbilir, 2014). In the analysis of deseed content, dethralistic statistics are acted on the basis of dethralistic statistics to reach the findings and are mostly used for analysis of frequency and percentage distributions. The most obvious difference from metaanalysis and meta-synthesis is that it can use both types of data (qualitative and quantitative) (Dinçer, 2018). In this study, deseed content analysis was used because it was carried out in Turkey to analyze the thesis conducted in Turkey with qualitative methods and to determine whether the theses met the need in terms of quality and number and what kind of research was needed.

\section{Collection of Data and Research Inclusion Criteria}

In accordance with the purpose of the study, the results of the examination conducted at the National Thesis Center of the Higher Education Institution (YÖKTEZ) are limited to 66 graduate thesis that were found to have been completed on mathematics literacy carried out in Turkey between 2008 and 2020. Within the scope of the study, data not related to the subject of mathematics literacy and non-accessable studies were not included in the research. Criteria sampling method, which is one of the purpose sampling methods, was used when determining the theses to be examined within the scope of the study. Postgraduate theses that constitute the subject of the study; It was obtained as a result of scanning the words "mathematics literacy/literacy" in the keyword field in the "thesis name" section of the thesis made in YÖKTEZ.

\section{Coding and Analysis of Data}

A coding form was prepared in accordance with the purpose of the study, and it was determined whether the studies were in accordance with the criteria for inclusion in the meta-synthesis and a comparison was made between the studies. Firstly, the studies within the scope of the research, which were read in detail, were examined according to the research problems, coded according to each theme and recorded as a summary. The 
carefully reviewed studies were coded as A1, A2, A3 ...... A66. Unnecessary parts were removed from the data that was repeatedly read.

\section{Validity and Reliability of the Study}

In the study, the purpose of the research and the research questions were clearly expressed and validity and reliability were tried to be ensured. The studies were examined for 2 months after being downloaded from the thesis center in order to avoid any errors in the coding process. Then, a summary table was created in line with the research questions and codings were carried out. In order for the coding to be reliable, the analysis of the researchers was repeated after a certain period of time, and it was observed that the coding was $91 \%$ consistent with each other. It has been checked by two experts to increase consistency between coders. In the research, the studies are given in the form of tables and graphics for the reader to understand more easily. Analyzing the data and determining common themes are explained in detail. Only frequencies are included in the graphs and tables statistically.

\section{FINDINGS}

\section{Distribution of thesis on mathematics literacy according to the year and type of thesis on mathematics literacy}

In Figure 1, of the postgraduate theses on mathematical literacy; The distribution of theses according to years and types is given.

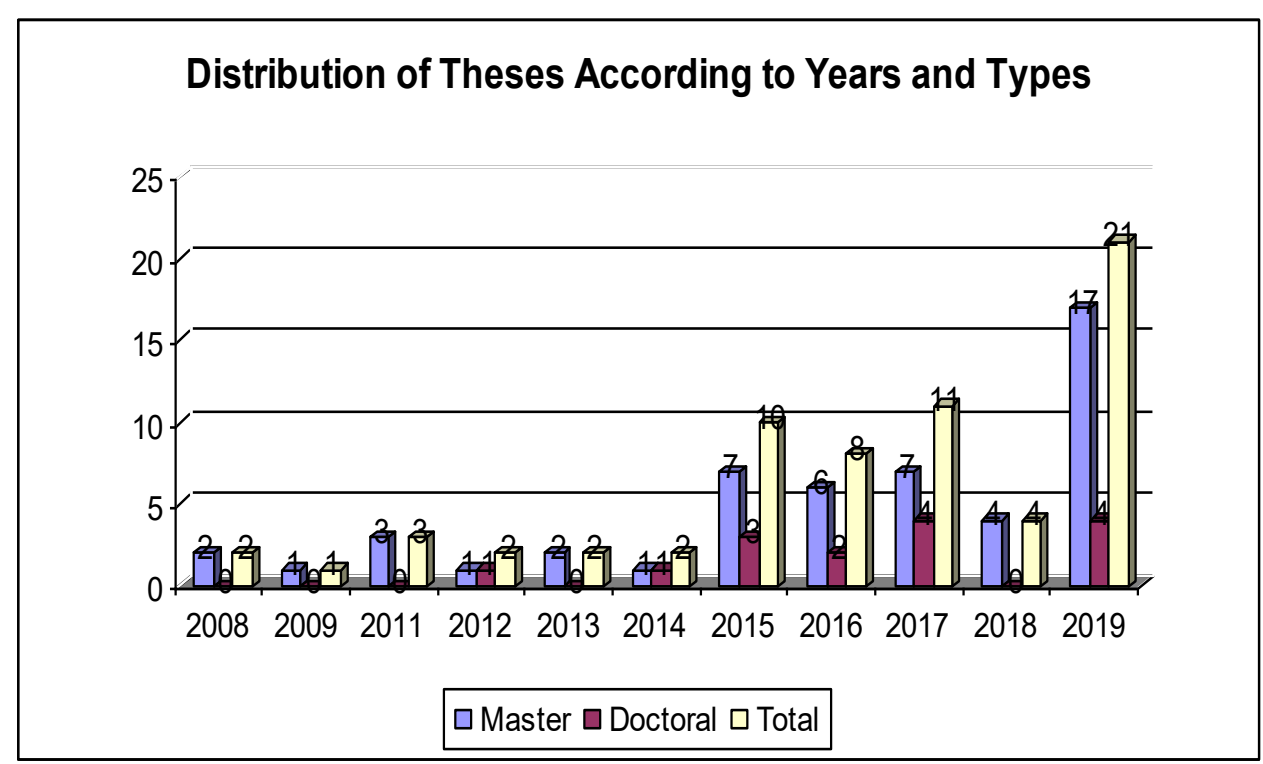

Figure 1. Distribution of Theses According to Years and Types 
In Figure 1, it was determined that the number of master's and doctoral dissertations completed in Turkey since 2008 increased in the present day and that the studies carried out in the last 5 years (2015-2019) constituted about $80 \%$ of the total studies. It was found that there was a decrease in the number of thesis performed only in 2018 and no doctoral dissertation was performed this year. In addition, it is seen that master's and doctoral dissertations are completed no more than 2019. Another important conclusion according to the findings is that master's numbers are approximately three times the number of doctoral dissertations (master's $f=51$, phD f $=15$ ).

\section{Distribution of Examined Theses According to Universities}

The distribution of postgraduate theses on mathematical literacy according to universities is shown in Figure 2.

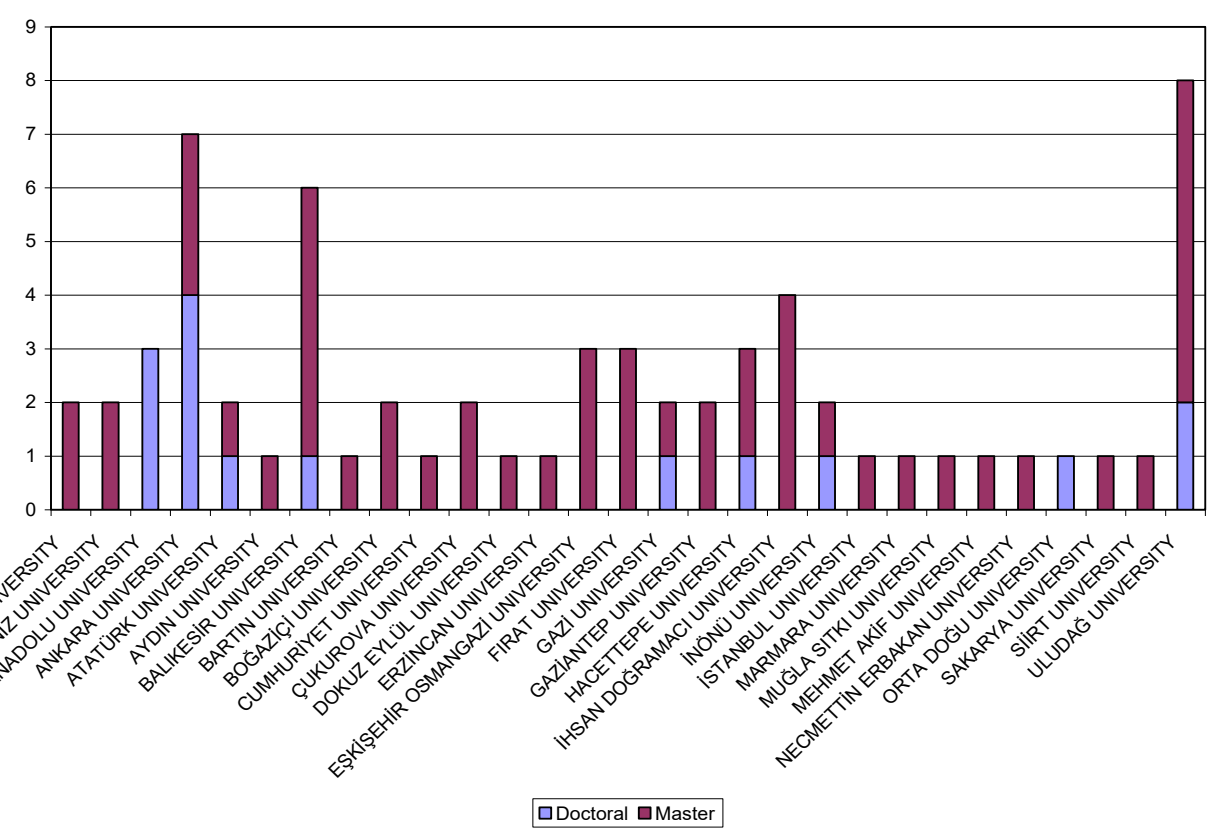

Figure 2. Distribution of Theses According to Universities

When the distribution of theses on mathematics literacy in the field of mathematics education is examined, it is seen that Uludağ University ( $f=8$ ) and Anadolu University ( $f$ $=7$ ) have completed more thesis to other universities. These universities are respectively followed by Balıkesir University ( $f=6$ ), İhsan Doğramacı Bilkent University ( $\mathrm{f}=4$ ), Anadolu University ( $\mathrm{f}=3$ ) and other universities. When the distribution in terms of master and doctorate thesis is examined, it is seen that the most master thesis is from Uludağ University and the doctorate thesis is from Ankara University. 


\subsection{Objectives of the Examined Theses}

Findings regarding the aims of postgraduate theses on mathematics literacy in the field of mathematics education are given in Table 1.

Table 1.

Data on the Aims of Graduate Thesis on Mathematics Literacy

\begin{tabular}{llc}
\hline Aims & Theses & $\mathrm{f}$ \\
\hline The effect of different approaches and & A10, A14, A15, A25, A26, A32, & \\
variables to ML & A33, & 13 \\
& A38, A54, A58, A60, A61, A64 & \\
\hline & A2, A7, A8, A9, A12, A13,A19,
\end{tabular}
A29,

Examination of ML in the context of $\mathrm{A} 45$,

A30, A37, A39, A42, A43, A44, PISA

A48, A49, A50, A53, A55, A59,

A62, A65

Examining the relationship between

A18, A28, A31, A34, A35,

ML and self-efficacy perceptions and A40, A41

different variables

Examination of ML and problem
solving skills

A1, A3, A16, A17, A47, A52,

A57, A63

levels

$\mathrm{A} 21, \mathrm{~A} 22, \mathrm{~A} 27$

ML and program review

A23, A24

encountered in solving ML questions

Scale / questionnaire development for ML

A11, A46

Identifying mediator variables related to ML

*ML: Mathematics Literacy 
As seen from Table 1, a significant part of the graduate theses examined were found to be for the purpose of examining mathematics literacy on the PISA axis ( $\mathrm{f}=23$ ) and examining the effect of different approaches and variables to mathematics literacy $(\mathrm{f}=13)$. Studies on the PISA axis of mathematics literacy has often been on measurement immutability, comparing country results and substance analysis. Studies of ML levels and development $(\mathrm{f}=8$ ), study of the relationship between mathematical literacy and self-efficacy perceptions and different variables ( $\mathrm{f}=7$ ), study of mathematics literacy and problem-solving ability $(\mathrm{f}=7$ ) were also found to be thesis. Apart from these, it has been determined that there are few studies carried out for other purposes.

\section{Methods Used in the Examined Theses}

Findings regarding the methods used in the postgraduate theses on mathematics literacy in the field of mathematics education are given in Table 2.

Table 2.

Data on The Methods of Graduate Theses on Mathematics Literacy

\begin{tabular}{|c|c|c|c|}
\hline Research Method & & Theses & $\mathrm{f}$ \\
\hline \multirow{3}{*}{ Quantitative } & Experimental & A11, A20, A26, A28, A32, A36, A64 & 7 \\
\hline & Survey & $\begin{array}{l}\mathrm{A} 2, \mathrm{~A} 5, \mathrm{~A} 9, \mathrm{~A} 13, \mathrm{~A} 14, \mathrm{~A} 18, \mathrm{~A} 19, \mathrm{~A} 24, \mathrm{~A} 35, \\
\mathrm{~A} 38, \mathrm{~A} 43, \mathrm{~A} 44, \mathrm{~A} 46, \mathrm{~A} 48, \mathrm{~A} 50, \mathrm{~A} 53, \mathrm{~A} 57, \\
\mathrm{~A} 61, \mathrm{~A} 62, \mathrm{~A} 63\end{array}$ & 20 \\
\hline & $\begin{array}{l}\text { Relational } \\
\text { research }\end{array}$ & A12, A34, A37, A54, A59, A66 & 6 \\
\hline \multirow{4}{*}{ Qualitative } & Case Study & $\mathrm{A} 3, \mathrm{~A} 16, \mathrm{~A} 23, \mathrm{~A} 51, \mathrm{~A} 52$ & 5 \\
\hline & $\begin{array}{l}\text { Document } \\
\text { analysis }\end{array}$ & A21 & 1 \\
\hline & $\begin{array}{l}\text { Teaching } \\
\text { Experiment }\end{array}$ & $\mathrm{A} 4, \mathrm{~A} 60$ & 2 \\
\hline & Action Research & A22 & 1 \\
\hline Mixed Method & & $\begin{array}{l}\text { A1, A6, A8, A10, A15, A17, A25, A27, A31, } \\
\text { A33, A40, A47, A55, A56, A58 }\end{array}$ & 15 \\
\hline $\begin{array}{l}\text { Descriptive } \\
\text { Survey }\end{array}$ & & $\mathrm{A} 7, \mathrm{~A} 29, \mathrm{~A} 30, \mathrm{~A} 39, \mathrm{~A} 41, \mathrm{~A} 42, \mathrm{~A} 45, \mathrm{~A} 49, \mathrm{~A} 65$ & 9 \\
\hline
\end{tabular}

When Table 2 is examined, the survey method, which is among the quantitative research methods, has been used in most of the theses. Four of the studies using survey 
management are doctoral dissertations (A2, A5, A9, A61). All of the experimental studies done are master thesis. It was observed that the mixed method was used in three doctoral theses (A1, A6, A8) and twelve master theses (A10, A15, A17, A25, A27, A31, A33, A40, A47, A55, A56, A58). Two of the studies used by the descriptive survey method are doctoral dissertations (A7, A49), the others are master's thesis (A29, A30, A39, A41, A42, A45, A65). Three of the studies using the case study method are doctorate (A3, A51, A52) and two are master's thesis (A16, A23). Teaching experiment (A4, A60), document analysis (A21), action research (A22) methods were also used in theses. A4 and $\mathrm{A} 60$ of these studies are doctoral dissertations.

As seen in Table 2, it was determined that the researchers preferred the survey method among the quantitative research methods in their studies. This is followed by mixed research methods, experimental research methods and descriptive survey. It has been determined that the least preferred research methods in theses are case study, document analysis, teaching experiment and action research.

\section{Sample Characteristics of the Examined Theses}

Findings regarding the preferred sampling of postgraduate theses on mathematics literacy in the field of mathematics education are given in Figure 3, Figure 4 and Figure 5. (* Four studies were not included in the analysis since they did not contain a sample)

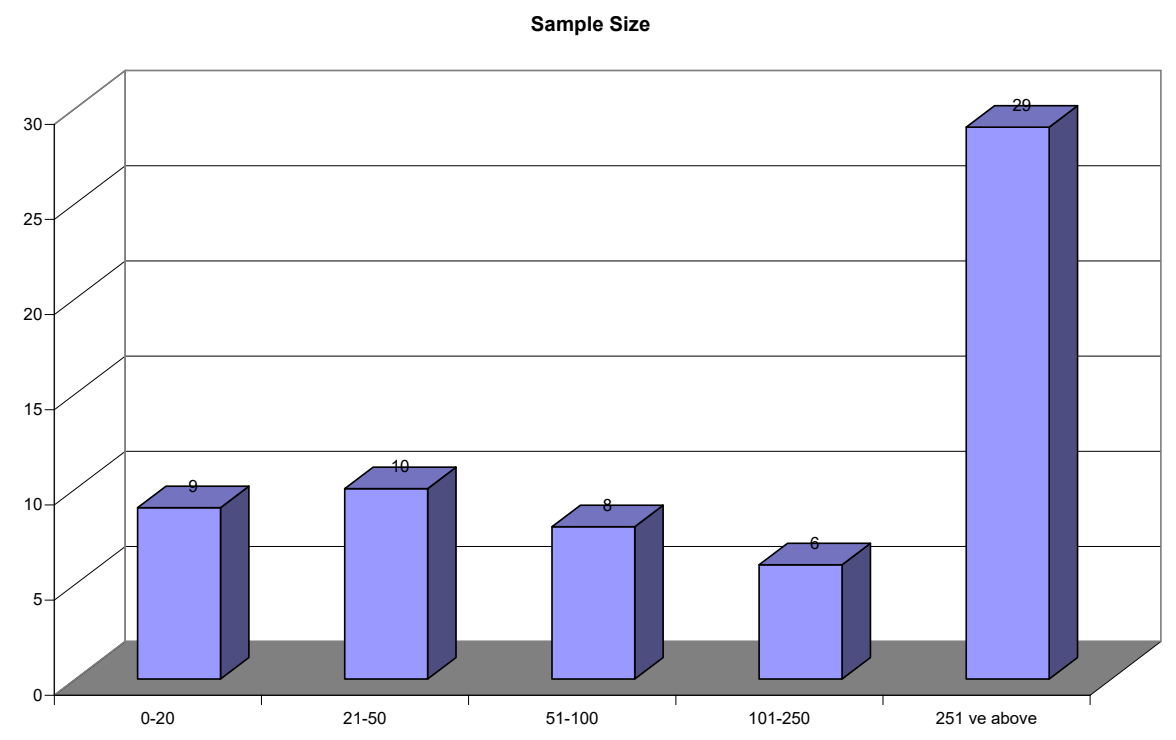

Figure 3. Sample Size of Theses

When Figure 3 is examined, it was determined that the sample size of most of the theses ( $f=29$ ) is over 251. Most of these theses are studies with a large number of participants in the sample and using PISA data. There are 9 thesis studies with sample size 0-20 and 
10 thesis studies with 21-50. In one study, a thesis with two classroom teachers and 9 students was found. The total of theses with a sample size of 101-250 and 51-100 is 14 .

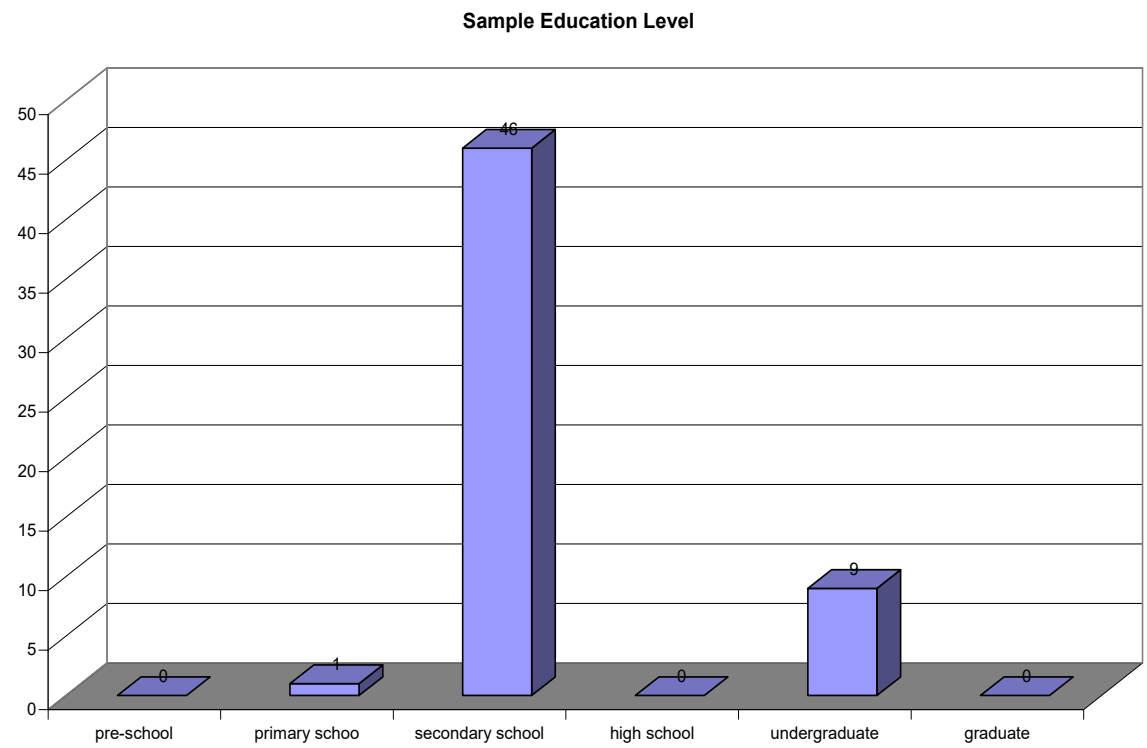

Figure 4. Sample Education Level

When Figure 4 and Figure 5 were examined, it was seen that the samples of most of the theses were composed of students $(f=46)$ and the education level of these students was secondary school ( $f=46$ ). These were followed by theses whose education level was undergraduate ( $f=9$ ) and the group of students who were applied ( $f=8)$. In the group expressed as mixed, there are groups from at least two different groups (student and teacher). ( $f=5$ ) In the study, there is no study whose education level is preschool and graduate. Theses that were not included in the study because there was no sample are document analysis and item analysis of literacy questions

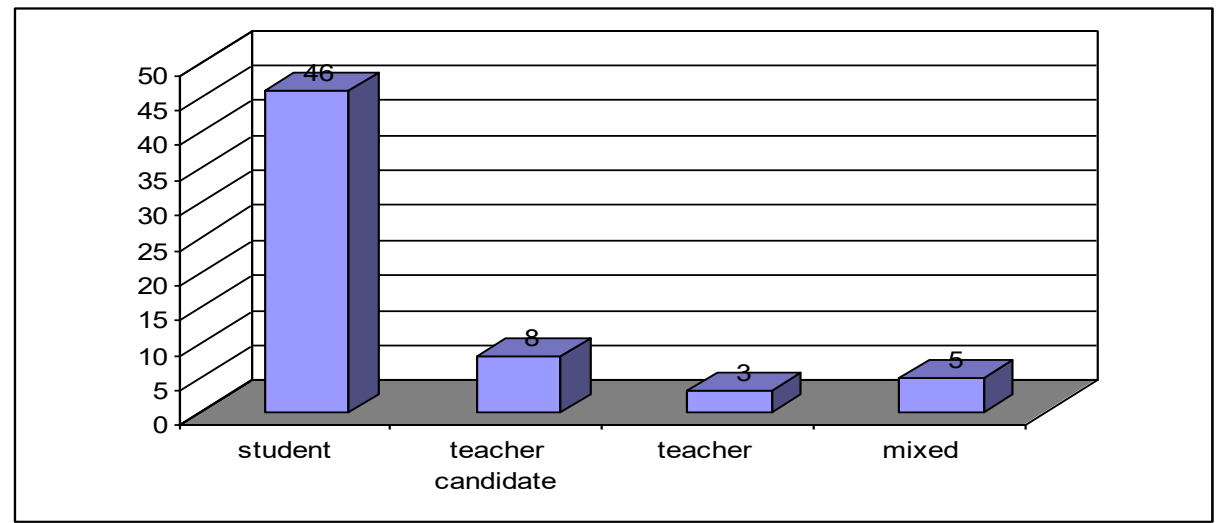

Figure 5. Group where the application is made 


\subsection{Data Collection Tools Used in Thesis Examined}

The data collection tools preferred by graduate theses on mathematics literacy in the field of mathematics education are given below in Figure 6.

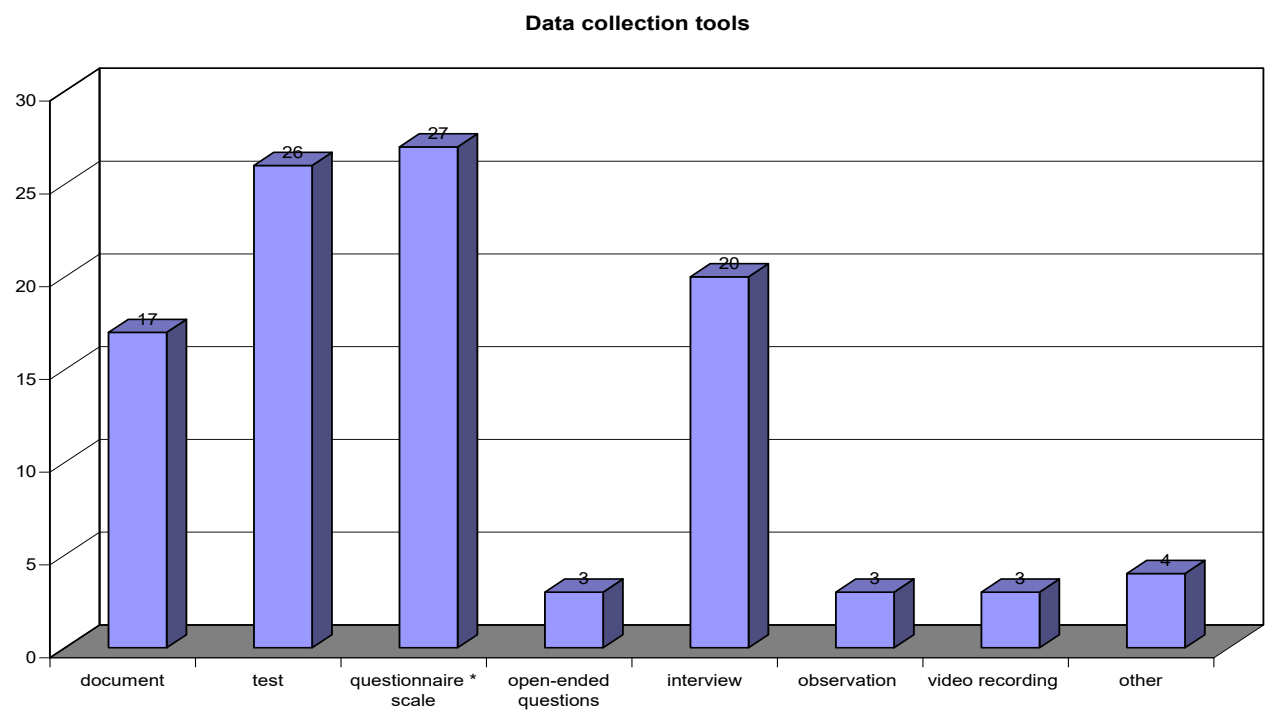

Figure 6. Data collection tools preferred in theses

As seen in Figure 6, it has been determined that in the theses examined within the scope of the research, most of the surveys / scales and tests are used as data collection tools, followed by interviews / interviews and documents respectively. It has been observed that the most used achievement tests as tests. In some studies, test, scale and interview were used together. As a result of the examinations, it was seen that documents were used in 17 studies, most of them were PISA exam results and reports. On the other hand, it was determined that the least preferred data collection tools were open-ended questions, video recording and observation.

\section{RESULTS, DISCUSSIONS AND SUGGESTIONS}

In the subject of mathematics literacy in Turkey, it has been seen that the number of master's and doctoral dissertations completed since 2008 has increased and gained popularity especially in the last 5 years (2015-2019). All over the world, the concept of mathematics literacy has been recognized in real sense by the PISA exams that the OECD has started to implement since 2000 and has influenced the educational policies of countries and led to the change of mathematics teaching programs. With the effect of this in Turkey, the mathematics education and training program was renewed in the 2004-2005 academic year and the concept of mathematics literacy was adopted. For this 
reason, the studies carried out in the field of mathematics literacy between 2000 and 2005 are outnnming and mathematics is considered to be understood as the importance of literacy (Firat, 2019). It is seen that the master's and doctoral theses were completed in 2019 at the most. According to the findings, another important result is the observation that the number of master's degrees is approximately three times the number of doctoral dissertations. Since the mathematics literacy theses made at the doctoral level require a broad scope, their application time is also long. This makes it obligatory to carry out such theses supported by TUBITAK and similar projects. Although the number of studies on mathematical literacy increases gradually, it requires a separate interest and expertise. Due to the scarcity of doctoral studies in this field, the number of studies conducted by researchers at universities in this field is decreasing. Similarly, in the study conducted by Oguz-Haçat and Demir (2019), it was determined that master's thesis was more quantitative than doctoral thesis, and the reason for this can be explained as the status of taking part in graduate programs (master's and doctorates) in university institutions in the field of education and the preference of studies on literacy.

When the distribution of thesis on mathematics literacy according to universities is examined, it is seen that more thesis studies are carried out in this field than other universities at Uludag University and Anadolu University. These universities are followed by Balikesir University, Ihsan Doğramacı Bilkent University, Anadolu University and other universities respectively. When the master's and doctoral thesis distributions are compared, it is seen that master's thesis studies are carried out the most at Uludag University and doctoral thesis studies are carried out at Ankara University. Haçat Oguz and Demir (2018) explain the high number of thesis prepared in established universities, with the fact that the foundation years of universities are earlier than others and they have more academic opportunities. It draws attention to the fact that master's and doctoral theses are mostly done in Gazi University.

It was determined that a significant part of the graduate theses examined were examined on the PISA axis of mathematics literacy and studies were also seen to investigate the effect of different approaches and variables to mathematics literacy. Studies using PISA data generally focused on the immutability of measuring mathematics literacy, comparing country results and substance analysis. It has also been observed that there are theses for the purpose of examining mathematics literacy levels and development, examining the relationship between perceptions of mathematics literacy and self-suffration and different variables, and examining mathematics literacy and problem solving ability. It has been determined that there are few studies other than these and for other purposes.

When the findings regarding the methods used in the graduate theses on mathematics literacy in the field of mathematics education were examined, it was determined that the researchers preferred the scanning method among the quantitative research methods in their studies. This is followed by mixed research methods, experimental research 
methods and descriptive scanning. It has been observed that the least preferred research methods in theses are case study, document analysis, teaching experiment and action research. Since exams and activities involving literacy have been applied frequently in recent years in our country, it is thought that this situation will affect the mathematics literacy awareness of teachers and students. As the applications increase, qualitative methods such as case study and action research can be expected to increase.

Most of the thesis is the studies using PISA exam data, which are carried out with the participation of a large number of people. It has been observed that the most of the theses are sampled by students and their level of study is secondary school. This result is similar to the result of the study conducted by Haçat Oguz and Demir (2019). It is seen that the number of studies with secondary school students is very small (Taşkın, Ezentaş \& Altun, 2018; Köysuren \& Üzel, 2018; Yeniel, 2019). Pisa exam, which is evocoted with mathematics literacy, is applied to 15-year-old (high school) students. The study with secondary school students in most of the theses is important for the determination of literacy levels from early on. These were followed by undergraduate students as a level of study and theses as teacher candidates as the group implemented. There is no study with a sample learning level of preschool and postgraduate. Since early mathematics literacy has an impact on school readiness skills, research should be conducted on the potential effects of math literacy in preschool education. When the studies examined are evaluated, it is notet that the studies carried out with teachers are very few. However, it is important to focus on the mathematics literacy of teachers in the studies to be carried out. Because this process can be expressed as an ongoing interaction from teacher to student.

When the data collection tools preferred by graduate theses on mathematics literacy in the field of mathematics education were examined, it was seen that surveys/scales and tests were preferred as data collection tools. This may be due to the fact that the studies carried out are more experimental studies. It was determined that interviews/interviews and documents followed them in turn. While it was determined that the most success tests were used as tests, tests, scale and interviews were used together in some studies. However, it has been determined that the least preferred data collection tools are open-end questions, video recording and observation.

Considering that one of the important factors that will increase math literacy levels is teacher and teacher candidates, it is of great importance to determine and increase the level of mathematics literacy of undergraduate students (teacher candidates) and teachers. For this reason, it is important to increase the number of mathematics literacy studies at the undergraduate level and with teachers.

When we look at the thesis examined in our research, mathematics literacy and primary school level study were not found. Since the literacy foundations of the students who will take pisa exams are carried out at the primary school level, mathematics literacy studies can be carried out with primary school students. In addition, according to pisa exam results, our country has achieved below average in mathematics literacy. The 
average scores in mathematics of the 79 countries participating in PISA 2018 vary between 325 and 591. The average score in mathematics of the 79 participating countries was calculated as 459 and the average score in mathematics of 37 OECD countries was 489 , and Turkey ranked 42 nd in mathematics among 79 countries with an average score of 454.ranked 33rd out of 37 OECD countries (MEB, 2019). In order to improve this situation, the number of qualitative studies for the discovery and implementation of methods and techniques that can increase the level of mathematics literacy can be increased.

\section{References}

Altun, M. (2020). Matematik Okuryazarlığı El Kitabı: Yeni Nesil Soru Yazma ve Öğretim Düzenleme Teknikleri [Mathematical Literacy Handbook: Next Generation Question Writing and Instructional Editing Techniques]. Bursa: Aktüel Alfa Akademi Yayıncllık.

Çepni, S. (2016). PISA ve TIMSS Mantığını ve Sorularını Anlama [Understanding PISA and TIMSS Logic and Questions]. Ankara: Pegem Akademi.

Çalık, M., \& Sözbilir, M. (2014). İçerik Analizinin Parametreleri [Parameters of Content Analysis]. Eğitim ve Bilim, 39 (174), 33-38.

De Lange, J. (2003). Mathematics for literacy. B. L. Madison ve L. A. Steen (Eds.), Quantitative literacy: Why numeracy matters for schools and colleges. Princeton, NJ: The National Council on Education and the Disciplines, 75-89.

Dinçer, S. (2018). Content Analysis in for Educational Science Research: Meta-Analysis, MetaSynthesis, and Descriptive Content Analysis. Bartın Üniversitesi Eğitim Fakültesi Dergisi, 7(1), 176-190.

Doyle, K. (2007). The Teacher, The Tasks: Their Role in Students? Mathematical Literacy. In Watson, Janeand Beswick, Kim, Eds. Proceedings 30th annual conference of the Mathematics Education Research Group of Australasia - Mathematics: Essential Research, Essential Practice, 246-254.

Durlak, J.A. (1995), Reading and understanding multivariate statistics. Washington, DC: American Psychological Association.

EARGED, (2005). PISA 2003 Project National Final Report. Ankara: MEB-Education Research and Development Department.

Edge, D. L. (2009). Math Literacy: The Relationship of Algebra, Gender, Ethnicity, Socioeconomic Status, and Avid Enrollment With High School Math Course Completion and College Readiness. University of North Texas. Access address :https://search.proquest.com/openview/0a1145a64a709990201873a68e6fd310/1?pqorigsite $=$ gscholar $\& \mathrm{cbl}=18750 \&$ diss $=\mathrm{y}$.

Fırat, İ. (2019). Türkiye'de Matematik Okuryazarlık İle İlgili 2020 Yılına Kadar Yapılan Çalışmaların Doküman Analizi Yöntemiyle Incelenmesi [Investigation By The Method of Document Analysis Of Studies On Mathematics Literacy In Turkey Until 2020]. (Master Thesis). Accessed from YÖK Thesis database (Thesis number: 620110). 
Graven, M., \& Venkatakrishnan, H. (2006). Emerging successes and tensions in the implementation of Mathematical Literacy. Learning and Teaching Mathematics, 4, 5-9.

Oğuz Haçat, S., \& Demir, F.B. (2018). Sosyal Bilgiler Eğitimi Üzerine Yapılan Doktora Tezlerinin Değerlendirilmesi (2002-2018) [Evaluation Of The Doctoral Dissertations Conducted On Social Studies Education (2002-2018)]. Avrasya Uluslararası Araştırmalar Dergisi, 6 (15), 948973 .

Oğuz Hacat, S., \& Demir, F. B. (2019). Eğitim Alanında Okuryazarlık Üzerine Yapılan Lisansüstü Tezlerin Analizi [Analysis of Postgraduate Theses on Literacy in the Field of Education]. Anadolu Kültürel Araştırmalar Dergisi, 3(2), 116-145.

Hardianti, S., \& Zulkardi, Z. (2019). Students Mathematical Literacy Abilities in Solving PISA Typemath Problem With LRT Context. Journal Of Physics: Conference Series, 1315 (1), 1-7.

İskenderoğlu, T. A., \& Baki, A. (2011). İlköğretim 8. Sınıf Matematik Ders Kitabındaki Soruların PISA Matematik Yeterlik Düzeylerine Göre Sinıflandırılması [Classification of the Questions in an 8th Grade Mathematics Textbook with Respect to the Competency Levels of PISA]. Eğitim ve Bilim. (36) 161, 287-301.

Julie, C. (2006). Teachers' Preferred contexts for Mathematical Literacy As Possible Initiators For Mathematics For Action. African Journal of Research in Mathematics, Science and Technology Education, 10 (2), 49-58.

Kabael, T. (2018). Matematik Okuryazarlığı ve PISA [Mathematical Literacy and PISA]. Ankara: Anı Yayıncillk.

Kaiser, G., \& Willander, T. (2005). Development Of Mathematical Literacy: Results Of An Empirical Study. Teaching Mathematics and its Applications, 24 (2), 48-60.

Kilpatrick, J. (2001). Understanding Mathematical Literacy: The Contribution Of Research. Educational Studies in Mathematics, 47 (1), 101-116.

Köysüren, M., \& Devrim, Ü. (2018). Matematik Öğretiminde Teknoloji Kullanımının 6. Sınıf Öğrencilerinin Matematik Okuryazarlığına Etkisi [The Effect of Using Technology in Mathematics Teaching to Mathematical Literacy of 6th Grade Students']. Necatibey Ĕgitim Fakültesi Elektronik Fen ve Matematik Eğitimi Dergisi, 12 (2), 81-101.

Lutzer, C. V. (2005). Fostering Mathematical Literacy. Problems. Resources and Issues in Mathematics Undergraduate Studies, 15 (1), 1-6.

MEB. (2009). Elementary Mathematics Lesson 6-8 Curriculum. Ankara: Ministry of Education, Directorate of Education and Discipline.

MEB. (2016). PISA 2015 Final Report. Ankara: Ministry of National Education.

Mullen, J. (2009). Enhancing mathematical literacy. (Master's thesis). School of Arts and Sciences St. John Fisher College.

NCTM. (1989). Curriculum and Evaluation standards for school mathematics. Reston, VA: The Council.

Ojose, B. (2011). Mathematics literacy: Are we able to Put The Mathematics We Learning to Everyday Use. Journal of Mathematics education, 4 (1), 89-100.

Özgen, K., \& Bindak, R. (2008). Matematik Okuryazarlığı Öz-Yeterlik Ölçeğinin Geliştirilmesi [The Development of Self-Efficacy Scale for Mathematical Literacy]. Kastamonu Eğitim Dergisi, 16 (2), 517-528. 
Prabawati, M., \& Herman, T. (2019). Mathematical Literacy Skills Students of The Junior High School in Term of Gender Differences. Journal of Physics: Conference Series, 1315 (1),1-7.

Rifandi, R., Puspita, V., \& Mulyati, A. (2019). The Validity of Problem Solving Based Teaching Material on Mathematical Literacy in The Meintegrated Learning. Journal of Physics: Conference Series. 1317 (1).

Romberg, T. A. (2001). Mathematical literacy: What Does It Mean For School Mathematics. Wisconsin School News, 10, 5-8.

Sanjaya, F., Putu, W. D., Julie, H., Anggoro, A. Y., \& Rudhito, M. A. (2019). The Mathematics Education Department Students' Ability in Mathematical Literacy For Uncertainty Problems on PISA Adaptation Test. Journal Of Physics: Conference Series, 1366 (1), 1-8.

Solomon, Y. (2008). Mathematical Literacy: Developing Identities of inclusion. Routledge.

Umbara, U., \& Suryadi, D. (2019). Re-Interpretation of Mathematical Literacy Based on the Teacher's Perspective. International Journal of Instruction, 12(4), 789-806.

Taşkın, E., Ezentaş, R., \& Altun, M. (2018). Altıncı Sınıf Öğrencilerine Verilen Matematik Okuryazarlığı Eğitiminin Öğrencilerin Matematik Okuryazarlığı Başarısına Etkisi [The Effects of the Mathematics Literacy Education of the 6th Grade Students to Mathematics Literacy Achievement]. Kastamonu Eğitim Dergisi, 26 (6), 2069-2079.

Taufik, A. R., Pagiling, S. L., \& Dadi, O. (2019). The Process of Formulating in Mathematical Literacy in Solving PISA-Like problems Viewed From Cognitivestyle. IOP Conference Series: Earth And Environmental Science. 343 (1), 1-9.

Trapsilasiwi, D., Oktavianingtyas, E., Putri, I. W. S., Adawiyah, R., Albirri, E. R., Firmansyah, F. F., \& Andriani, Y. (2019). Mathematical Literacy of Male and Female Students in Solving PISA Problem by "Shapeand Space" Content. Journal of Physics: Conference Series. 1218 (1), 1-8.

Venkat, H., \& Graven, M. (2007). Insights into the implementation of Mathematical Literacy. African Journal of Research in Mathematics, Science and Technology Education, 11(2), 67-84.

Wolf, F. M. (1986). Meta-analysis: Quantitative methods for research synthesis. London: Sage Publications.

Yeniel, A. (2019). Seçmeli Matematik Uygulamaları Dersinin Öğrencilerin Matematik Okuryazarlık Düzeylerine ve Matematiğe Yönelik Tutumlarına Etkisi ve Öğretmen Görüşlerinin İncelenmesi [An investigation on the effect of elective math applications lessons on students' math literacy level and their math attitude and views of teachers]. (Master Thesis). Accessed from YÖK Thesis database (Thesis number: 544029). 
In the writing process of the study titled "Analysis of Thesis in Turkey between the years 2008-2020 on Mathematics Literacy", the rules of scientific, ethical and citation were followed; it was undertaken by the authors of this study that no falsification was made on the collected data. "Sakarya University Journal of Education Journal and Editor" had no responsibility for all ethical violations to be encountered, and all responsibility belongs to the authors and that the study was not submitted for evaluation to any other academic publishing environment. 


\title{
Türkiye'de 2008-2020 Yılları Arasında Matematik Okuryazarlığı Üzerine Yapılan Tezlerin Analizi
}

\author{
Ayşe Arzu ARI* $\quad$ Barış DEMİR ${ }^{* *}$
}

Öz. Son yıllarda matematik okuryazarlığı kavramı matematik eğitimi ile ilgili çalışmaların temel konusu haline gelmiştir. Mevcut durumda matematik okuryazarlığı ile ilgili çok sayıda lisansüstü tez olmasına rağmen bunların detaylı bir analizinin yapıldığı çalışmaya rastlanamamıştır. Bu çalışmanın amacı, Türkiye'de matematik okuryazarlı̆̆ı üzerine yapılan tezlerin nicelik ve nitelik olarak ihtiyacı ne ölçüde karşıladığını ne tür araştırmalara ihtiyaç olduğunu metasentez yöntemi kullanılarak analizini edip ortaya çıkarmaktır. Araştırmada 20082019 yılları arasında matematik okuryazarlığı konusunda çalışılan ve amaçlı örnekleme yöntemi ile belirlenen lisansüstü tezler analiz edilmiştir. Araştırmada incelenen lisansüstü tezler, Yüksek Öğretim Kurumu (YÖK) Ulusal Tez Tarama Merkezi veri tabanında yapılan tarama sonucu elde edilmiştir. Bu çalışma; 2019 yılına kadar matematik eğitimi alanında okuryazarlık üzerine tamamlandığı tespit edilen 66 (51 yüksek lisans ve 15 doktora) lisansüstü tezle sınırlıdır. Çalışmada elde edilen veriler, matematik okuryazarlığı ile ilgili tezlerin yapıldığı üniversite, yıllar ve türü, örneklem özellikleri, hedeflenen amaçlar, kullanılan yöntemler ve veri toplama araçları açısından incelenmiştir. Elde edilen veriler frekans ile grafikler ve tablolar yardımıyla gösterilmiştir. 2008 yılından itibaren hazırlanan yüksek lisans ve doktora tez sayısının, günümüze doğru gelindiğinde arttığı, doktora tez sayısının yüksek lisans tez sayısının üçte biri oranında olduğu ve en çok tezin Uludağ Üniversitesinden çıktığı görülmüştür. Araştırmada, tezlerin büyük bir kısmının matematik okuryazarlığının PISA bağlamında incelenmesi amacıyla gerçekleştirildiği tespit edilmiştir. Araştırma yöntemi olarak en çok nicel tarama yönteminin, veri toplama aracı olarak anket/ölçek ve testlerin kullanıldığı, öğrencilerle ve ortaokul düzeyinde yapılan çalışmaların çoğunlukta olduğu görülmüştür.

Anahtar Kelimeler: Matematik okuryazarlı̆̆ı, İçerik analizi, Tezler

\footnotetext{
* Orcid ID: https://orcid.org/0000-0002-0907-2663, Dr. Öğr. Üyesi, Kocaeli Üniversitesi, Matematik Eğitimi Anabilim Dalı, Türkiye, abural@kocaeli.edu.tr

** Orcid ID: https://orcid.org/0000-0001-6997-6413, Öğr. Gör., Kocaeli Üniversitesi, İşletme Yönetimi Programı Anabilim Dalı, Türkiye, barisprof@yahoo.com
} 


\section{GİRIş}

Temel bilgi ve becerilerin kazanılmasının ötesinde matematik öğrenmek, matematiksel düşünmeyi, problem çözme stratejilerini kullanmayı ve matematiğin günlük yaşamın ayrılmaz bir parçası olduğunu görmeyi içerir. (Milli Eğitim Bakanlığı [MEB], 2009). Matematiksel bilgi ve becerileri günlük yaşamda kullanma ise matematik okuryazarlığı ile ilişkilendirilmektedir. 2000 li yllların başında matematik eğitimcileri, matematik okuryazarlığının alanyazında ortak olarak kullanılabilecek tanımını ve matematik okuryazarlığı düzeyini ölçme çalışmalarında kullanılabilecek matematik okuryazarlığı modelini geliştirme çabasına girmişlerdir (Kabael, 2018).

Matematik okuryazarlı̆̆ı ifadesindeki okuryazarlık sözcüğü dilimizdeki karşllığından farklı olarak daha geniş bir anlama sahiptir. Dilimizde okuryazar olmak yazılı bir metni okuyabilme ve söyleneni yazma anlamında kullanılmaktadır ve kapsamı oldukça yüzeyseldir. Matematik okuryazarlığının İngilizcesi olan "mathematical literacy", matematiksel bir metni okuma ve söyleneni yazmadan daha geniş bir anlama sahiptir (Altun, 2020). Matematik okuryazarı olabilmek için bireyin iki duruma aynı anda sahip olması beklenir: ilki matematiksel işlemleri yapabilmek amacıyla hesaplamalar yapabilmesidir. Diğeri matematiğin hızla artan farklı alanlardaki uygulamalarını yapabilmesidir (Matematik Öğretmenleri Ulusal Konseyi National Council of Teachers of Mathematics [NCTM], 1989). Daha anlaşılır bir ifadeyle matematik okuryazarı bir bireyde önemli ölçüde matematiksel bilgi ve beceri gereklidir. Bu kavram, yalnızca sayısal işlem ve okuma-yazmadan oluşan öğeler olmayıp farklı durum ve koşullara uygulanabilme ve ilgili matematiksel uygulamaların birey tarafından çözebilme becerisini içermektedir. Matematik okuryazarlığı kavramı matematiksel güç, matematiksel yeterlik, matematiksel beceri, uzamsal ve sayısal okuryazarlı gibi tanımlamalarla yapılmakta ve karşılaştırılmaktadır (Çepni, 2016). Matematik okuryazarlığının kişiye, matematiğin modern dünyadaki oynadığı rolünün farkında olmasını ve anlamasını, günlük yaşam ile ilişkili uygulamaları yapabilmesini, becerilerin geliştirilmesini, sayısal ve uzamsal düşünmede yorumlama, güven duygusunu, günlük hayat durumlarında eleştirel analiz ve problem çözmeyi sağladığını söyleyebiliriz (Özgen ve Bindak, 2008).

Matematik okuryazarlığı, bir birey olarak yapıcı, özenli ve düşünceli olma ihtiyacıyla karşı karşıya kaldığımızda matematiği bireysel yaşamımızda kullanmanın, anlamanın ve matematiğin dünyadaki oynadığı rolü teşhis etmek, anlamak için bireysel kapasiteyi kullanmak ve sağlam bir nedene dayalı savunma yapmanın bir yoludur (İskenderoğlu ve Baki, 2011). Ayrıca matematik okuryazarlığı, matematiğin günlük hayattaki kullanım alanlarını fark etme ve ihtiyaçların karşılanması için matematikten olumlu anlamda faydalanma olarak tanımlanmakta ve bireyin matematiğin dünyadaki rolünü kavramasını sağlamaktadır (Eğitim Araştırma ve Geliştirme Dairesi [EARGED], 2005). Edge (2009) matematik okuryazarlığını, bilgi düzeyinin ötesinde matematiğin anlaşılması olarak ifade etmektedir. 
Sağladığı olanaklar ile matematik okuryazarlığı uluslararası sınavlarda da araştırılmaya başlanmıştır. Bu durum ile eğitim araştırmacıları, medya, politika belirleyicileri bu matematik okuryazarlığı alanındaki tartışmalara dahil olmuşlardır (Çepni, 2016). OECD (Ekonomik Kalkınma ve İşbirliği Örgütü-Organisation for Economic Co-operation and Development) tarafından düzenlenen ve ilk uygulaması 2000 yılında yapılmış olan PISA (Uluslararası Öğrenci Değerlendirme Programı-Programme for International Student Assessment) çalışması ile 15 yaş grubu öğrencilerinin matematik, fen ve anadilde okuryazarlık becerileri değerlendirilmektedir. Okuma, fen ve matematik alanlarındaki bilgi ve becerileri günlük yaşamda kullanma becerilerini 3 yıllık döngüler halinde ölçen PISA çalışmasının her uygulamasında bu alanlardan sadece birine ağırlık verilmektedir. $\mathrm{Bu}$ değerlendirmeyi yaparken okuryazarlık kavramı üzerinden ana alanları tanımlamaktadır. Okuryazarlık kavramı, öğrencilerin temel konu alanlarında çeşitli durumlarda karşılaştıkları sorunları tanımlama, yorumlama ve çözerken bilgi ve becerilerini kullanma, analiz etme, mantıksal çıkarımlar yapma ve etkili iletişim kurma becerisi olarak ifade edilmektedir (MEB, 2016).

Değerlendirmenin yapıldığı üç alandaki okuryazarlıklar şu şekilde tanımlanmaktadır (Kabael, 2018):

Okuma becerileri: Bireyin amaçlarını gerçekleştirmek, bilgi ve potansiyelini geliştirmek ve topluma katılmak için yazılı bir metni anlama, kullanma ve yansıtma kapasitesidir.

Fen okuryazarlığı: bireyin fen ile ilişkili konu ve fikirlere uğraşabilme becerisidir. Fen okuryazarı bir birey, fen ve teknoloji alanındaki olguların bilimsel açıklamasını gerektiği şekilde yapan, bilimsel soruları tasarlayıp değerlendiren, verileri yorumlayan ve bilimsel olarak ispatlayan, belirli bir mantık çerçevesinde yapılan söylemlere katılmaya istek duyan becerilere sahiptir.

Matematik okuryazarlığı: Öğrencilerin matematiği farklı bağlamlarda formüle etme, kullanma ve yorumlama kapasitesidir. $\mathrm{Bu}$ kapasite, matematiksel muhakeme oluşturabilme ve olguları tanımlama, açıklama ve tahmin etme gibi matematiksel kavramları, süreçleri, gerekçeleri ve araçları kullanabilmeyi içerir. 


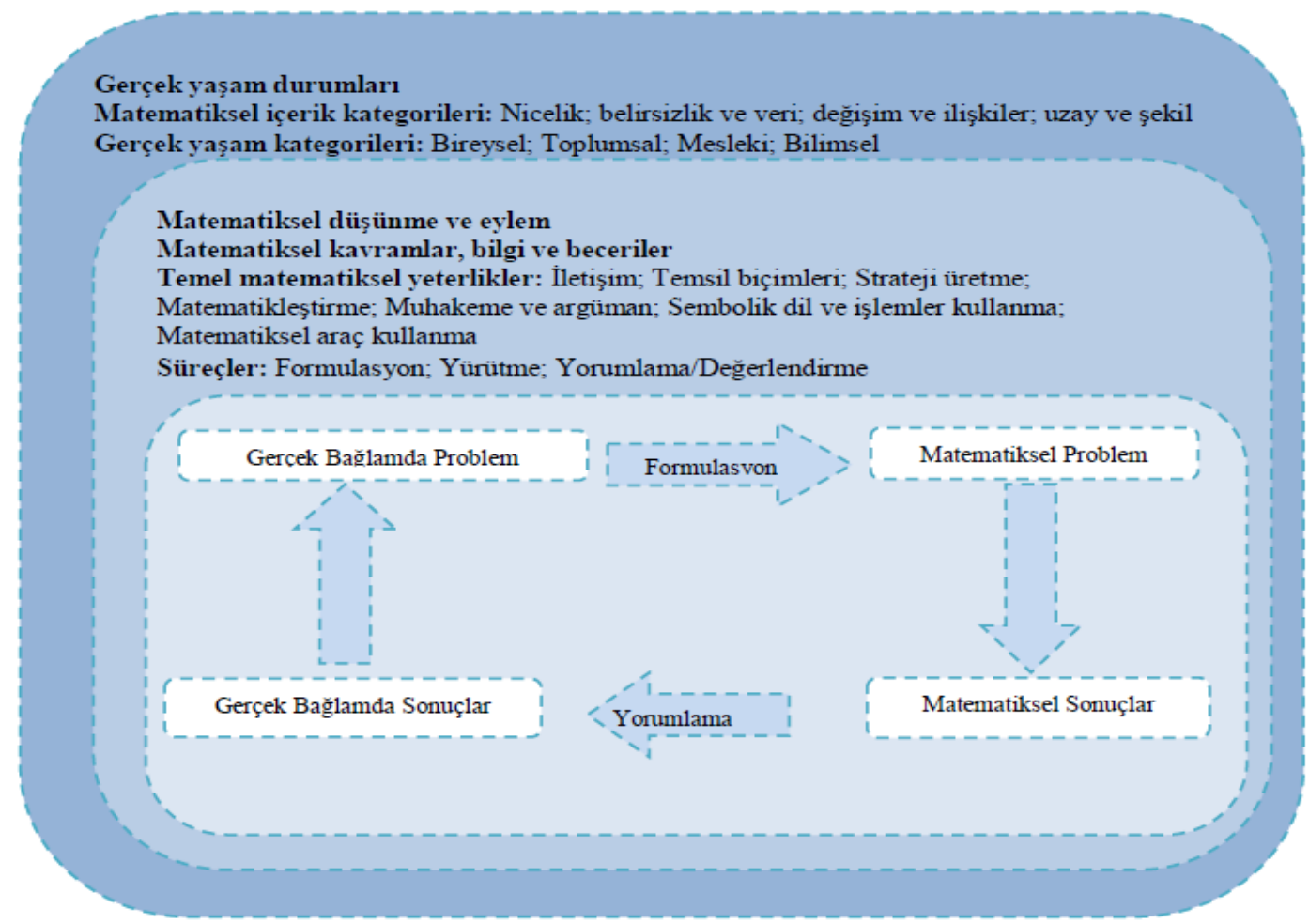

Şekil 1. Matematik okuryazarlı̆̆ı değerlendirme çerçevesinin genel özellikleri (MEB, 2016)

Şekil 1'de verilen dıştaki dikdörtgensel kutu gerçek yaşam probleminin dayandığı matematiksel içerik kategorilerini ve problemin gerçek yaşamın hangi bağlamı ile ilgili olduğunu gösterir. Problemin dayandığı matematiksel içerik PISA matematik okuryazarlığı çerçevesinin "içerik" bileşenini, gerçek yaşam kategorileri ise "bağlam" bileşenini oluşturur. İçteki dikdörtgensel kutu ise problemin çözüm sürecindeki zihinsel süreçleri ve bu süreçlerde işe koşulması gereken matematiksel yeterlikleri içermektedir (Kabael, 2018).

Literatür incelendiğinde yurt dışında matematik okuryazarlık çalışmalarının (Romberg, 2001; Kilpatrick, 2001; De Lange, 2003; Kaiser ve Willander, 2005; Lutzer, 2005; Graven ve Venkatakrishnan, 2006; Julie, 2006; Doyle, 2007; Venkat ve Graven, 2007; Solomon, 2008; Mullen, 2009; Ojese, 2011; Hardianti ve Zulkardi, 2019; Umbara ve Suryadi, 2019; Prabawati ve Herman, 2019; Rifandi, Puspita ve Mulyati, 2019; Sanjaya, Putu, Julie, Anggoro ve Ruthio, 2019; Taufik, Pagiling ve Dadi, 2019; Trapsilasiwi vd., 2019) yapıldığı gözlenmiştir. Ülkemizde ise Fırat (2019) tarafından yüksek lisans tez çalışmasında matematik okuryazarlığı açısından Türkiye'nin durumunun belirlenmesi amacıyla doküman analizi yöntemi ile makale ve tezler taranmıştır. $\mathrm{Bu}$ araştırma ise sadece yüksek lisans ve doktora tezleri içerik analizi yöntemi kullanılarak ek araştırma sorularıyla yürütülmüştür. 
Türkiye'de matematik eğitimi alanında matematik okuryazarlığı üzerine yapılan tezlerin hangi yıllarda ve üniversitelerde, hangi amaçlarla, hangi yöntemlerle, hangi örneklemler üzerinde, hangi veri toplama aracı kullanılarak yapıldığı eleştirel bir bakış açısıyla değerlendirilmesi açısından önemli görülmektedir. Ayrıca matematik okuryazarlığı konusunda araştırma yapan veya yapmayı düşünen araştırmacılara da ışık tutacağı düşünülmektedir.

Bu araştırmada, Türkiye'de yapılmış matematik okuryazarlığı ile ilgili tezlerin içerik analizi yöntemi kullanılarak incelenmesi ve matematik eğitiminde bu konuya nasıl bir yaklaşım olduğunun ve tezlerin nitelik ve nicelik bakımından ihtiyacı ne ölçüde karşıladığını ne tür araştırmalara ihtiyaç olduğunu ortaya konması amaçlanmıştır. Araştırmada aşağıdaki sorulara cevap aranmıştır.

Matematik okuryazarlığını konu alan tezlerin yapıldığı yıl ve türüne göre dağılımı nasıldır?

Matematik okuryazarlığını konu alan tezlerin üniversitelere göre dağılımı nasıldır?

Matematik okuryazarlığını konusunda yapılan tezlerde hedeflenen amaçlar nelerdir?

Matematik okuryazarlığını konu alan tezlerde kullanılan yöntemler nelerdir?

Matematik okuryazarlığını konu alan tezlerde tercih edilen örneklem özellikleri nelerdir?

Matematik okuryazarlığını konu alan tezlerde kullanılan veri toplama araçları nelerdir?

\section{YÖNTEM}

$\mathrm{Bu}$ bölümde araştırmanın modeline ve veri toplama araçları hakkındaki bilgilere yer verilmiştir.

\section{Araştırma Modeli}

Matematik eğitimi alanında matematik okuryazarlığı üzerine yapllan lisansüstü tezlerin değerlendirilmesini amaçlayan bu çalışmada betimsel içerik analizi yöntemi kullanılmıştır. İçerik analizleri; araştırılan bilginin yaygınlaştırılması ve gelecek araştırmaların, politikaların, uygulamaların ve kamu algısının şekillendirilmesinde önemli bir role sahip olan araştırma sentezleridir. Bunları, en genel anlamda metaanaliz, meta sentez (tematik içerik analizi) ve betimsel içerik analizi olarak üçe ayırabiliriz. (Çalık ve Sözbilir, 2014). Meta-analiz; aynı konu üzerinde farklı zamanlarda ve yerlerde yapılmış olan bireysel çalışmaların deneysel bulgularının birleştirilmesi, sentezlenmesi ve yorumlanması amacıyla kullanılan istatistiksel işlemleri içeren nicel bir uygulamadır (Wolf, 1986; Durlak, 1995; Ak. Çalık ve Sözbilir, 2014). Meta-sentez (tematik içerik analizi) aynı konu üzerine yapılan araştırmaların tema veya ana şablonlar oluşturularak eleştirel bir bakış açısıyla sentezlenmesi ve yorumlanmasını içerirken betimsel içerik analizi; belirli bir konu üzerinde yapılan çalışmaların ele alınıp eğilimlerinin ve araştırma sonuçlarının tanımlayıcı bir boyutta değerlendirilmesini içeren sistematik çalışmalardır (Çalık ve Sözbilir, 2014). Betimsel içerik analizinde 
bulgulara ulaşmak için betimsel istatistikler temelinde hareket edilmekte ve çoğunlukla frekans ve yüzde dağılımları analiz için kullanılmaktadır. Meta-analiz ve meta-sentezden en belirgin farkı her iki veri türünü de (nitel ve nicel) kullanabilmesidir (Dinçer, 2018). Bu çalışmada da matematik okuryazarlığı ile ilgili Türkiye'de yürütülen tezlerin nitel yöntemlerle analiz edilmesi ve tezlerin nitelik ve sayı bakımından ihtiyacı karşılayıp karşılamadığı, ne tür araştırmalara ihtiyaç olduğunun tespit edilmesi amaçlandığından betimsel içerik analiz kullanılmıştır.

\section{Verilerin Toplanması ve Araştırmaya Dahil Edilme Kriterleri}

Araştırmanın amacına uygun olarak Yüksek Öğretim Kurumunun YÖK Ulusal Tez Merkezinde (YÖKTEZ) yapılan inceleme sonucu 2008-2020 ylları arasında Türkiye'de gerçekleştirilen matematik okuryazarlığı üzerine tamamlandığı tespit edilen 66 lisansüstü tezle sınırlıdır. Çalışma kapsamında, matematik okuryazarlığı konusu ile ilgili olmayan veriler ve erişime açık olmayan çalışmalar araştırmaya dahil edilmemiştir. Çalışma kapsamında incelenecek tezler belirlenirken amaçsal örnekleme yöntemlerinden biri olan ölçüt örnekleme yöntemi kullanılmıştır.

Çalışmanın konusunu oluşturan lisansüstü tezler; YÖKTEZ' de yapılan tezlerinin "tez adı" bölümünde, anahtar kelime alanına "matematik okuryazarlığı/okuryazarlık" kelimelerinin yazılarak taranması sonucu elde edilmiştir.

\section{Verilerin Kodlanması ve Çözümlenmesi}

Çalışmanın amacına uygun olarak bir kodlama formu düzenlenerek, araştırmada çalışmaların meta-senteze dâhil edilme ölçütlerine uygun olup olmadığı belirlenmiş ve çalışmalar arasında karşılaştırma yapılmıştır. İlk olarak detaylı bir şekilde okunan araştırma kapsamındaki çalışmalar araştırma problemlerine göre incelenerek her bir temaya göre kodlanıp özet olarak kaydedilmiştir. Dikkatli bir şekilde incelenen çalışmalara A1, A2, A3 ...... A66 şekilde kod verilmiştir. Tekrar tekrar okunan verilerden gereksiz kısımlar çıkarılmıştır.

\section{Araştırmanın Geçerlik ve Güvenirliği}

Çalışmada araştırmanın amacı ve araştırma soruları açık bir şekilde ifade edilerek geçerlilik ve güvenirliliği sağlanmaya çalışılmıştır. Çalışmalar kodlama sürecinde hata olmaması için tez merkezinden indirildikten sonra 2 ay süre zarfında incelenmiştir Daha sonra araştırma soruları doğrultusunda özet tablosu oluşturularak kodlamalar gerçekleştirilmiştir. Kodlamaların güvenilir olması için belli bir süre sonra araştırmacılar analizleri tekrar yapılmış, kodlamaların birbiri ile \%91 oranında tutarlı olduğu görülmüştür. Kodlayıcılar arasında tutarlılığı artırmak için iki uzmana kontrol ettirilmiştir.

Araştırmada çalışmaların okuyucu tarafından daha kolay anlaşılması için tablolar ve grafikler şeklinde verilmiştir. Verilerin analiz edilmesi ve ortak temaların belirlenmesi ayrıntılı bir şekilde açıklanmıştır. Grafik ve tablolarda istatistiki olarak sadece frekanslara yer verilmiştir. 


\section{BULGULAR}

Bu kısımda çalışma sonucunda elde edilen bulgular verilmiştir.

\subsection{Matematik okuryazarlığını konu alan tezlerin yapıldığı yıl ve türüne göre dağılımı}

Şekil 1'de matematik okuryazarlığı üzerine yapılan lisansüstü tezlerin; yıllara ve tezlerin türlerine göre dağılımı verilmiştir.

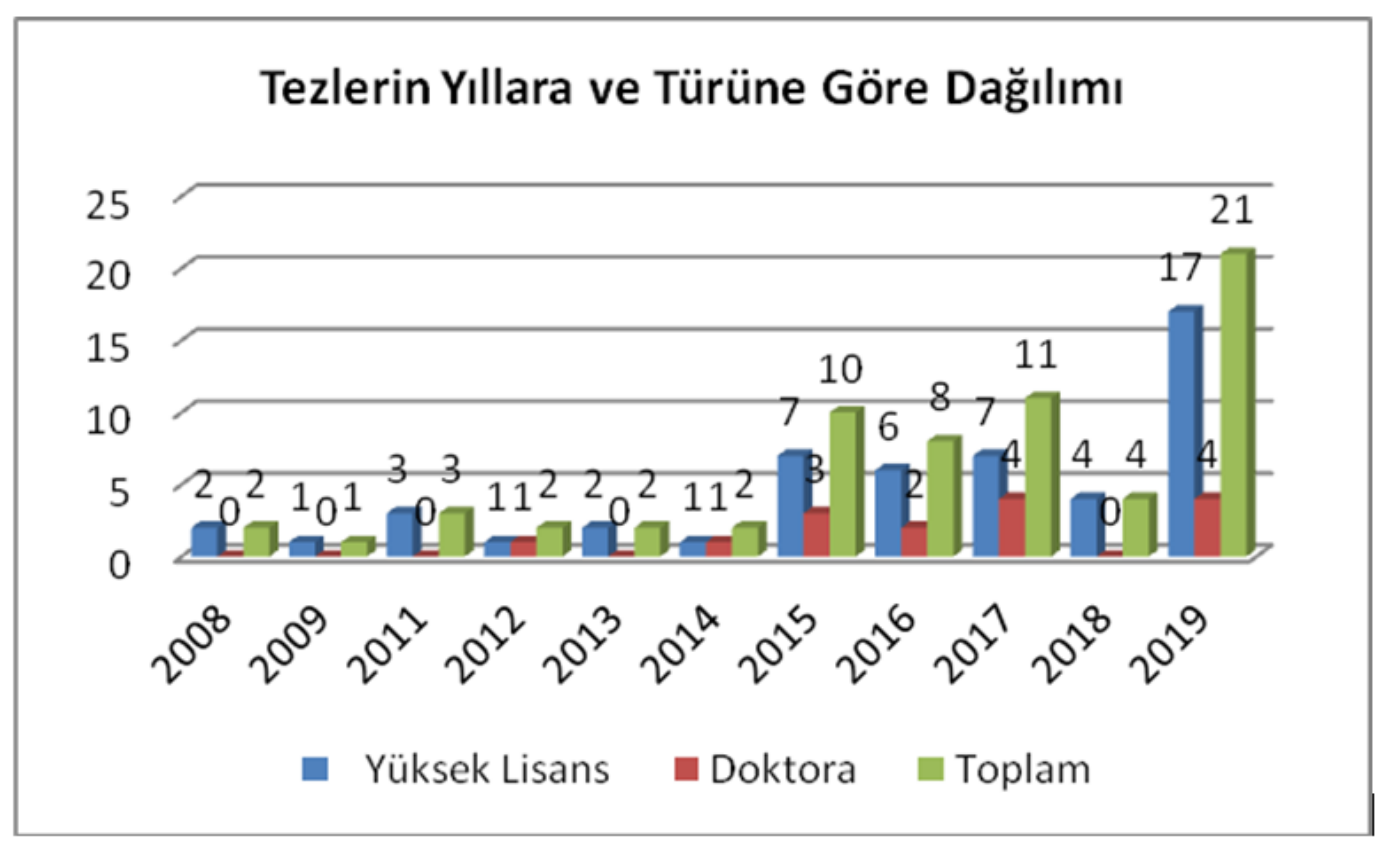

Şekil 1. Tezlerin Yıllara ve Türüne Göre Dağılımı

Şekil 1'de Türkiye'de matematik okuryazarlığı konusunda, 2008 yılından itibaren bitirilen yüksek lisans ve doktora tez sayısının, günümüze doğru gelindiğinde arttığı ve son 5 yılda (2015-2019) yapılan çalışmaların toplam çalışmaların yaklaşık \%80'ini oluşturduğu tespit edilmiştir. Sadece 2018 yılında yapılan tez sayısında bir azalma olduğu ve bu yılda doktora tezi yapılmadığı tespit edilmiştir. Ayrıca yüksek lisans ve doktora tezlerinin en fazla 2019 yılında tamamlandığı görülmektedir. Bulgulara göre önemli başka bir sonuç ise yüksek lisans sayılarının doktora tez sayılarının yaklaşık üç katı (yüksek lisans $\mathrm{f}=51$, doktora $\mathrm{f}=15$ ) olduğunun gözlemlenmesidir.

\section{2. İncelenen Tezlerin Üniversitelere Göre Dağılımı}

Matematik okuryazarlığı üzerine yapılan lisansüstü tezlerin üniversitelere göre dağılımı Şekil 2'de gösterilmiştir. 


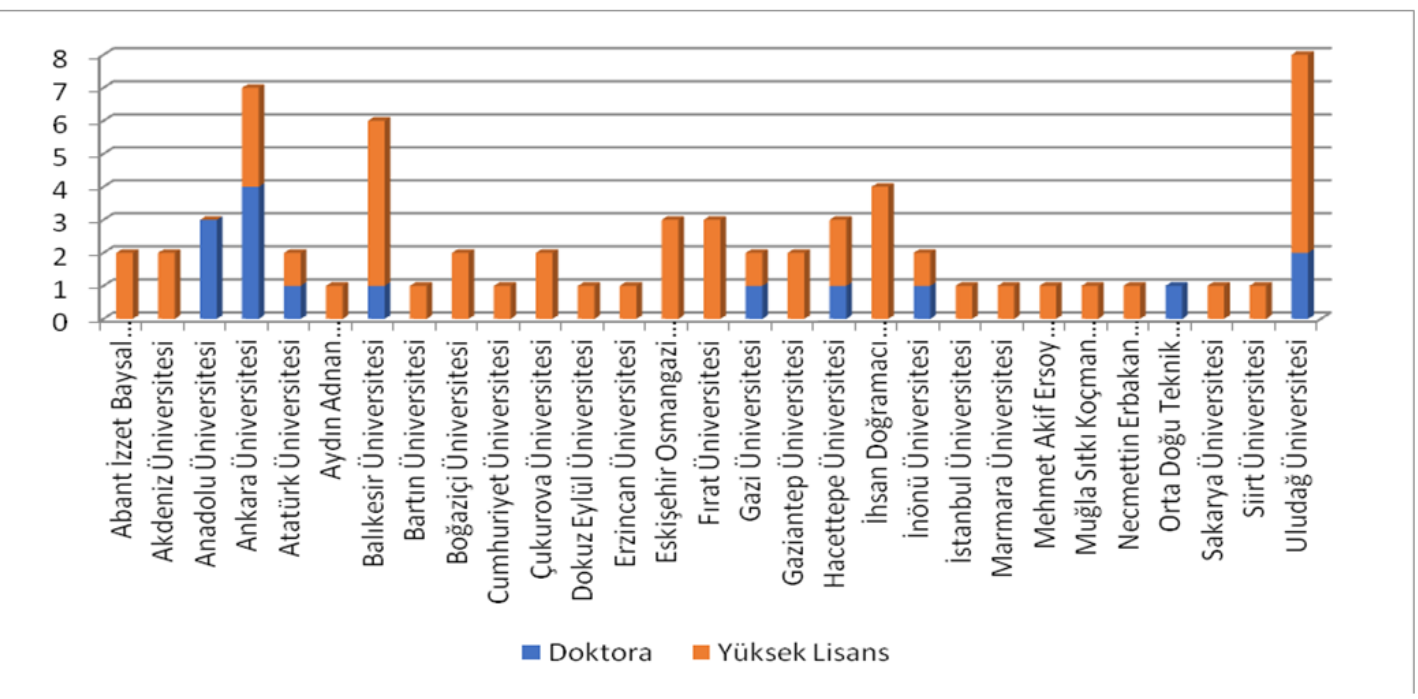

Şekil 2. Tezlerin Üniversitelere Göre Dağılımı

Matematik eğitimi alanında matematik okuryazarlığı üzerine yapılan tezlerin üniversitelere göre dağılımı incelendiğinde Uludağ Üniversitesi ( $f=8$ ) ve Anadolu Üniversitesi'nin ( $\mathrm{f}=7$ ) diğer üniversitelere daha fazla tez tamamladığı görülmektedir. $\mathrm{Bu}$ üniversiteleri sırasıyla Balıkesir Üniversitesi ( $f=6$ ), İhsan Doğramacı Bilkent Üniversitesi $(\mathrm{f}=4)$, Anadolu Üniversitesi $(\mathrm{f}=3$ ) ve diğer üniversiteler takip etmektedir. Yüksek lisans ve doktora tezi açısından dağılım incelendiğinde en çok yüksek lisans tezinin Uludağ Üniversitesi, doktora tezinin ise Ankara Üniversitesinden çıktığı görülmektedir.

\section{3.İncelenen Tezlerin Amaçları}

Matematik eğitimi alanında matematik okuryazarlığı üzerine yapllan lisansüstü tezlerin amaçlarına ilişkin bulgular Tablo 1'de verilmiştir.

Tablo 1

Matematik Okuryazarlığı Üzerine Yapılan Lisansüstü Tezlerin Amaçlarına İlişkin Veriler

\begin{tabular}{|c|c|c|}
\hline Amaçlar & Tezler & $\mathrm{f}$ \\
\hline $\begin{array}{l}\text { MO’ya farklı yaklaşımların ve } \\
\text { değişkenlerin etkisi }\end{array}$ & $\begin{array}{l}\text { A10, A14, A15, A25, A26, A32, } \\
\text { A33, } \\
\text { A38, A54, A58, A60, A61, A64 }\end{array}$ & 13 \\
\hline MO’nın PISA bağlamında incelenmesi & $\begin{array}{l}\text { A2, A7, A8, A9, A12, A13,A19, } \\
\text { A30, A37, A39, A42, A43, A44, } \\
\text { A45, }\end{array}$ & 23 \\
\hline
\end{tabular}


A48, A49, A50, A53, A55, A59,

A62, A65

MO ve öz yeterlik algıları ile farklı A18, A28, A31, A34, A35,

değişkenler arasındaki ilişkinin A40, A41 7 incelenmesi

MO ve problem çözme becerisi incelenmesi

MO gelişiminin ve düzeylerin incelenmesi A1, A3, A16, A17, A47, A52, A57, A63

8

MO ve program incelenmesi

A21, A22, A27 3

MO sorularının çözümünde

karşılaşılan zorluklar ve kavram A23, A24

yanılgıları

MO’na yönelik ölçek/anket

geliştirilmesi

A11, A46

MO ile ilgili aracı değişkenleri belirlemek

*MO: Matematik okuryazarlığı

Tablo 1'den görüldüğü gibi incelenen lisansüstü tezlerin önemli bir bölümü matematik okuryazarlığını PISA ekseninde incelenmesi $(\mathrm{f}=23)$ ve matematik okuryazarlığına farklı yaklaşımların ve değişkenlerin etkisinin incelenmesi (f=13) amacıyla yapıldığı tespit edilmiştir. Matematik okuryazarlığının PISA eksenindeki çalışmalar genellikle ölçme değişmezliği, ülke sonuçlarını karşılaştırma ve madde analizi üzerine olmuştur. MO düzeylerinin ve gelişiminin incelenmesi $(\mathrm{f}=8)$, matematik okuryazarlığı ve öz yeterlik algıları ile farklı değişkenler arasındaki ilişkinin incelenmesi (f=7), matematik okuryazarlığını ve problem çözme becerisi incelenmesi (f=7) amacıyla da yapılan tezler olduğu görülmüştür. Bunların dışında kalan ve diğer amaçlarla yapılan çalışmaların az sayıda olduğu belirlenmiştir.

\section{4. İncelenen Tezlerde Kullanılan Yöntemler}

Matematik eğitimi alanında matematik okuryazarlığı üzerine yapılan lisansüstü tezlerde kullanılan yöntemlere ilişkin bulgular Tablo 2'de verilmiştir. 
Tablo 2

Matematik Okuryazarlı̆̆ı Üzerine Yapılan Lisansüstü Tezlerin Yöntemlerine İlişsin Veriler

\begin{tabular}{|c|c|c|c|}
\hline \multicolumn{2}{|c|}{ Araştırma yöntemi } & Tezler & $\mathrm{f}$ \\
\hline \multirow{3}{*}{ Nicel } & Deneysel & $\mathrm{A} 11, \mathrm{~A} 20, \mathrm{~A} 26, \mathrm{~A} 28, \mathrm{~A} 32, \mathrm{~A} 36, \mathrm{~A} 64$ & 7 \\
\hline & Tarama & $\begin{array}{l}\text { A2, A5, A9, A13, A14, A18, A19, A24, } \\
\text { A35, A38, A43, A44, A46, A48, A50, } \\
\text { A53, A57, A61,A62, A63 }\end{array}$ & 20 \\
\hline & $\begin{array}{l}\text { İlişkisel } \\
\text { araştırma }\end{array}$ & A12, A34, A37, A54, A59, A66 & 6 \\
\hline \multirow{4}{*}{ Nitel } & Durum Çalışması & A3, A16, A23, A51, A52 & 5 \\
\hline & Doküman analizi & $\mathrm{A} 21$ & 1 \\
\hline & Öğretim Deneyi & $\mathrm{A} 4, \mathrm{~A} 60$ & 2 \\
\hline & $\begin{array}{l}\text { Eylem } \\
\text { Araştırması }\end{array}$ & A22 & 1 \\
\hline Karma & & $\begin{array}{l}\text { A1, A6, A8, A10, A15, A17, A25, A27, } \\
\text { A31, A33, A40, A47, A55, A56, A58 }\end{array}$ & 15 \\
\hline $\begin{array}{l}\text { Betimsel } \\
\text { Tarama }\end{array}$ & & $\begin{array}{l}\text { A7,A29, A30, A39, A41, A42, A45, A49, } \\
\text { A65 }\end{array}$ & 9 \\
\hline
\end{tabular}

Tablo 2 incelendiğinde tezlerin önemli bir kısmında nicel araştırma yöntemleri içerisinde yer alan tarama yöntemi kullanılmıştır. Tarama yöntemi kullanılan çalışmaların dört tanesi doktora tezidir (A2, A5, A9, A61). Yapılan deneysel çalışmaların tamamı yüksek lisans tezidir. Üç tane doktora tezi (A1, A6, A8), on iki tane yüksek lisans tezinde (A10, A15, A17, A25, A27, A31, A33, A40, A47, A55, A56, A58) karma yöntemin kullanıldığı görülmüştür. Betimsel tarama yönteminin kullandığı çalışmaların iki tanesi doktora tezi (A7, A49), diğerleri yüksek lisans tezidir (A29, A30, A39, A41, A42, A45, A65). Durum çalışması yönteminin kullanıldığı çalışmalardan üçü doktora (A3, A51, A52), ikisi yüksek lisans tezidir (A16, A23). Öğretim deneyi (A4, A60), doküman analizi (A21), eylem araştırması (A22) yöntemleri de tezlerde araştırma yöntemi kullanılmıştır. Bu çalışmalardan A4 ve A60 doktora tezidir.

Tablo 2'de görüldüğü gibi araştırmacıların çalışmalarda en çok nicel araştırma yöntemlerinden tarama yöntemini tercih edildiği belirlenmiştir. Bunu karma araştırma yöntemleri, deneysel araştırma yöntemleri ve betimsel tarama izlemektedir. Tezlerde en az tercih edilen araştırma yöntemlerinin ise durum çalışması, doküman analizi, öğretim deneyi ve eylem araştırması olduğu tespit edilmiştir. 


\section{5. İncelenen Tezlerin Örneklem Özellikleri}

Matematik eğitimi alanında matematik okuryazarlı̆̆ üzerine yapılan lisansüstü tezlerin tercih ettikleri örnekleme ilişkin bulgular Şekil 3, Şekil 4 ve Şekil 5'de verilmiştir. ( ${ }^{*}$ Dört çalışma örneklem içermediği için analize dahil edilmemiştir.)

\section{Örneklem Büyüklüğü}

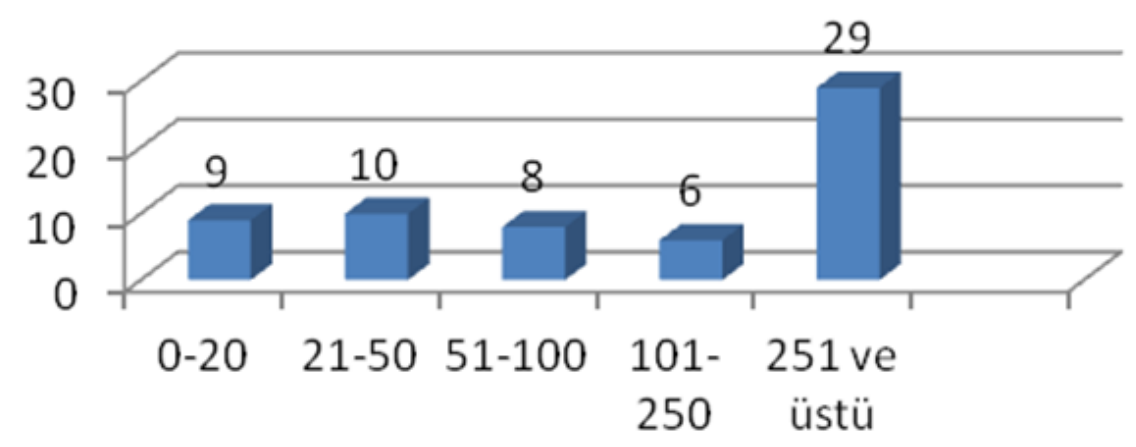

Şekil 3. Tezlerin Örneklem Büyüklüğü

Şekil 3 incelendiğinde, tezlerin büyük bir kısmının ( $\mathrm{f}=29)$ örneklem büyüklüğünün 251'in üzerinde olduğu belirlenmiştir. Bu tezlerin çoğunluğu örneklemde çok sayıda katılımcının bulunduğu ve PISA verilerinin kullanıldığı araştırmalardır. Örneklem büyüklüğü 0-20 olan 9adet ve 21-50 olan 10 adet tez çalışması bulunmaktadır. Bir çalışmalarda iki sınıf öğretmeniyle ve 9 öğrenciyle yürütülen birer teze rastlanmıştır. 101-250 arası ile 51-100 örneklem büyüklüğü olan tezlerin toplamı 14 adettir. 


\section{Örneklem Öğrenim Seviyesi}

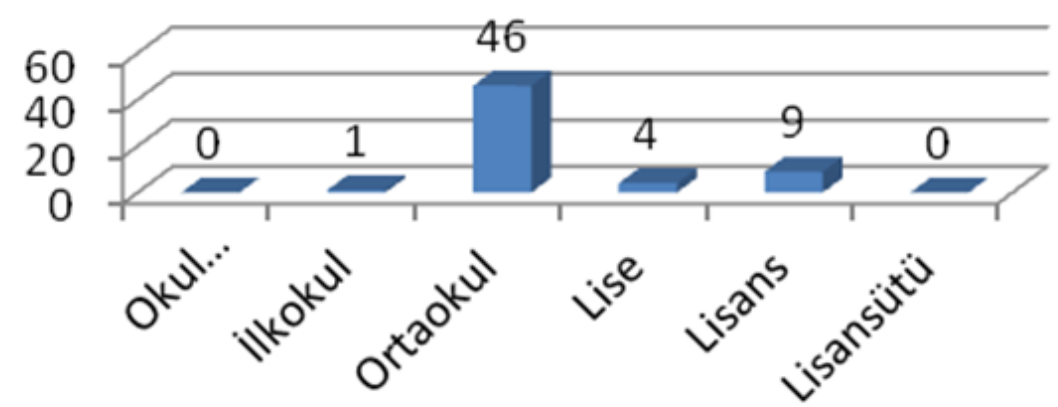

Şekil 4. Örneklem Öğrenim Seviyesi

Şekil 4 ve Şekil 5 incelendiğinde tezlerin çoğunluğunun örneklemini öğrencilerin oluşturduğu ( $\mathrm{f}=46)$ ve bu öğrencilerin öğrenim seviyelerinin ortaokul ( $\mathrm{f}=46)$ olduğu görülmüștür. Bunları öğrenim seviyesi lisans ( $\mathrm{f}=9$ ) ve uygulama yapılan grup öğretmen adayı ( $\mathrm{f}=8$ ) olan tezler izlemiştir. Karma olarak ifade edilen grupta en az iki farklı gruptan (öğrenci ve öğretmen) grubu yer almaktadır. (f=5) Çalışmada örneklem öğrenim düzeyi okul öncesi ve lisansüstü olan bir çalışma bulunmamaktadır. Örneklem olmadığı için çalışmaya dahil edilmeyen tezler doküman analizi ve okuryazarlık sorularının madde analizidir. 


\section{Uygulamanın Yapıldığı Grup}

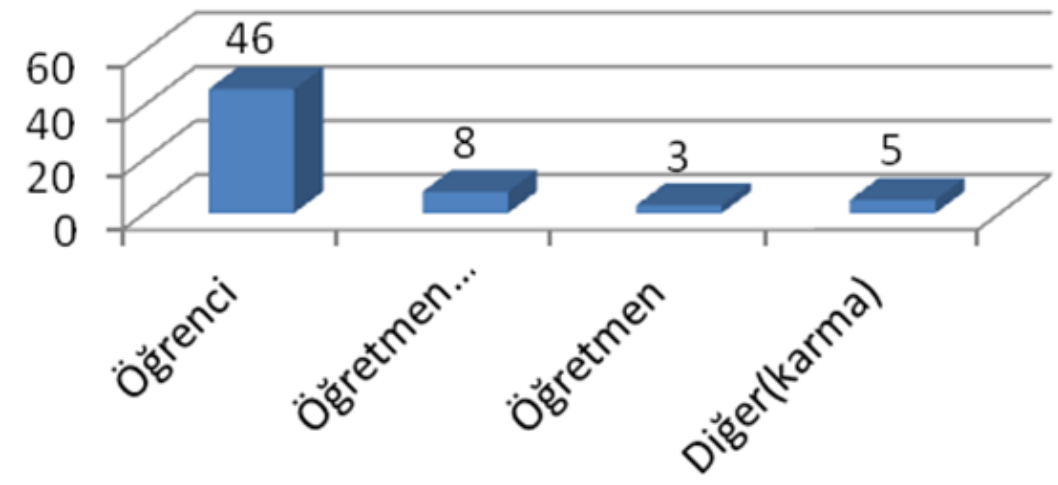

Şekil 5. Uygulamanın Yapıldı̆̆ı Grup

\section{6. İncelenen Tezlerde Kullanılan Veri Toplama Araçları}

Matematik eğitimi alanında matematik okuryazarlığı üzerine yapılan lisansüstü tezlerin tercih ettikleri veri toplama araçları aşağıda Grafik 6'da verilmiştir

\section{Veri Toplama Araçları}

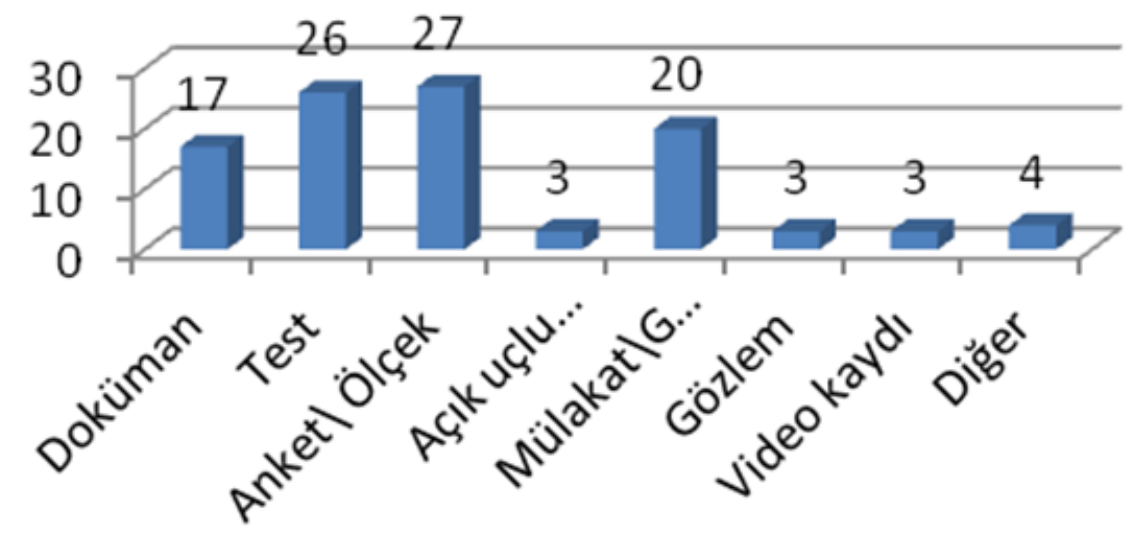

Şekil 6. Tezlerde tercih edilen veri toplama araçları 
Şekil 6'da görüldügü gibi araştırma kapsamında incelenen tezlerde en çok anket/ölçek ve testlerin veri toplama aracı olarak kullanıldığı bunları sırayla mülakat/görüşme ve dokümanların takip ettiği tespit edilmiştir. Test olarak en çok başarı testlerinin kullanıldığı görülmüştür. Bazı çalışmalarda test, ölçek ve görüşme bir arada kullanılmıştır. İncelemeler sonucunda 17 çalışmada doküman kullanıldığı bunların çoğunluğunun PISA sınav sonuç ve raporları olduğu görülmüştür. Buna karşın en az tercih edilen veri toplama araçlarının açık uçlu sorular, video kaydı ve gözlem olduğu belirlenmiştir.

\section{SONUÇ, TARTIŞMA VE ÖNERÍLER}

$\mathrm{Bu}$ kısımda araştırma problemleri doğrultusunda elde edilen sonuçlar tartışılmıştır.

Araştırmada elde edilen sonuçlara göre;

Türkiye'de matematik okuryazarlığı konusunda, 2008 yılından itibaren bitirilen yüksek lisans ve doktora tez sayısının, günümüze doğru gelindiğinde özellikle son 5 yılda (20152019) artış gösterdiği ve popülarite kazandığı görülmüştür. Tüm dünyada matematik okuryazarlık kavramı OECD’nin 2000 yılından itibaren uygulamaya başladığı PISA sınavları ile gerçek manada tanınmış ve ülkelerin eğitim politikalarını etkileyerek, matematik öğretim programlarının değişmesine öncülük etmiştir. Türkiye'de bununda etkisiyle matematik eğitim ve öğretim programı 2004-2005 öğretim yılında yenilenerek matematik okuryazarlık kavramının benimsendiği öğrenci merkezli yapılandırmacı eğitime geçilmiştir. Bu nedenle 2000-2005 yılları arasında matematik okuryazarlık alanında yapılan çalışmalar sayıca az olup matematik okuryazarlığın öneminin yeterince anlaşılmadığı düşüncesini oluşturmaktadır (Fırat, 2019). Yüksek lisans ve doktora tezlerinin en fazla 2019 yılında tamamlandığı görülmektedir. Bulgulara göre önemli başka bir sonuç ise yüksek lisans sayılarının doktora tez sayılarının yaklaşık üç katı olduğunun gözlemlenmesidir. Doktora düzeyinde yapılan matematik okuryazarlı̆̆ tezleri kapsam genişliği gerektirdiğinden uygulama süreleri de uzun olmaktadır. Bu ise bu tür tezlerin TUBİTAK ve benzeri projelerle desteklenerek yürütülmesini zorunlu kılmaktadır. Matematik okuryazarlığına yönelik çalışmaların sayısı giderek artsa da ayrı bir ilgi ve uzmanlık gerektirmektedir. Bu alanda gerçekleştirilen doktora çalışmalarının azlığından dolayı üniversitelerdeki araştırmacıların bu alanda yaptıkları çalışmaların sayısı azalmaktadır. Oğuz-Haçat ve Demir (2019) tarafından yapılan çalışmada da benzer olarak yüksek lisans tezlerinin doktora tezlerine göre nicelik olarak daha fazla olduğu tespit edilmiş olup bunun sebebi olarak, eğitim alanında yer alan üniversite kurumlarındaki lisansüstü programlarının (yüksek lisans ve doktora) yer alma durumları ve okuryazarlık alanı üzerine yapılan çalışmaların tercih edilme durumları şeklinde açılklanabileceği ifade edilmiştir.

Matematik okuryazarlığı üzerine yaplan tezlerin üniversitelere göre dağılımı incelendiğinde Uludağ Üniversitesi ve Anadolu Üniversitesinde diğer üniversitelere göre 
bu alanda daha fazla tez çalışması yapıldığı görülmektedir. Bu üniversiteleri sırasıyla Balıkesir Üniversitesi, İhsan Doğramacı Bilkent Üniversitesi, Anadolu Üniversitesi ve diğer üniversiteler takip etmektedir. Yüksek lisans ve doktora tezi dağılımları karşılaştırıldığındaysa yüksek lisans tezi çalışmalarının sayıca en çok Uludağ Üniversitesinde, doktora tezi çalışmalarının ise Ankara Üniversitesinde yapıldığı görülmektedir. Haçat Oğuz ve Demir (2018) köklü üniversitelerde hazırlanan tez sayısının fazla olmasını, üniversitelerin kuruluş yıllarının diğerlerine göre daha önce olması ve akademik olanaklara daha fazla sahip olmalarıyla açıklamaktadır. Yüksek lisans ve doktora tezleri en fazla Gazi Üniversitede yapıldığına dikkat çekmektedir.

İncelenen lisansüstü tezlerin önemli bir bölümü matematik okuryazarlığının PISA ekseninde incelendiği tespit edilmiş olup matematik okuryazarlığına farklı yaklaşımların ve değişkenlerin etkisinin araştırılması amacıyla yapılan çalışmalar da görülmüştür. PISA verileri kullanılarak yapılan çalışmalarda genellikle matematik okuryazarlığının ölçme değişmezliği, ülke sonuçlarını karşılaştırma ve madde analizi üzerine odaklanılmıştır. Matematik okuryazarlık düzeylerinin ve gelişiminin incelenmesi, matematik okuryazarlık ve öz yeterlik algıları ile farklı değişkenler arasındaki ilişkinin incelenmesi, matematik okuryazarlık ve problem çözme becerisi incelenmesi amacıyla da yapılan tezler olduğu da görülmüştür. Bunların dışında kalan ve diğer amaçlarla yapılan çalışmaların az sayıda olduğu belirlenmiştir.

Matematik eğitimi alanında matematik okuryazarlı̆̆ı üzerine yapılan lisansüstü tezlerde kullanılan yöntemlere ilişkin bulgular incelendiğinde araştırmacıların çalışmalarda en çok nicel araştırma yöntemlerinden tarama yöntemini tercih edildiği tespit edilmiştir. Bunu karma araştırma yöntemleri, deneysel araştırma yöntemleri ve betimsel tarama izlemektedir. Tezlerde en az tercih edilen araştırma yöntemlerinin ise durum çalışması, doküman analizi, öğretim deneyi ve eylem araştırması olduğu görülmüştür. Ülkemizde okuryazarlık içeren sınavlar ve etkinlikler son yıllarda sıklıkla uygulandığından bu durum öğretmen ve öğrencilerin matematik okuryazarlık farkındalıkları etkileyeceği düşünülmektedir. Uygulamalar artıkça daha az kullanılan durum çalışması, eylem araştırması gibi nitel yöntemlerinde artması beklenebilir.

Tezlerin büyük bir kısmını çok sayıda kişinin katılımıyla gerçekleştirilen PISA sınavı verilerinin kullanıldığı çalışmalar oluşturmaktadır. Tezlerin çoğunluğunun örneklemini öğrencilerin oluşturduğu ve bu öğrencilerin öğrenim seviyelerinin ortaokul olduğu görülmüştür. Bu sonuç Haçat Oğuz ve Demir (2019) tarafından yapılan çalışma sonucuyla benzerlik göstermektedir. Ortaokul öğrencileriyle yapılan çalışmaların sayısının çok az olduğu görülmektedir (Taşkın, Ezentaş ve Altun, 2018; Köysüren ve Üzel, 2018; Yeniel, 2019). Matematik okuryazarlığı ile çağrışım yapan PISA sınavına 15 yaş grubu (lise) öğrencilerine uygulanmaktadır. Tezlerin büyük bir kısmında ortaokul öğrencileri ile çalışma yapılmış olması okuryazarlık düzeylerinin erken dönemlerden itibaren tespit edilmesi açısından önem taşımaktadır. Bunları öğrenim seviyesi olarak lisans öğrencileri ve uygulama yapılan grup olarak da öğretmen adayı olan tezler izlemiştir. Çalışmada örneklem öğrenim düzeyi okul öncesi ve lisansüstü olan bir 
çalışma bulunmamaktadır. Erken matematik okuryazarlığının okula hazır bulunuşluk becerileri üzerindeki etkisi olduğundan okul öncesi eğitiminde matematik okuryazarlığının potansiyel etkileri ile ilgili araştırma yapılması gerekmektedir. İncelenen çalışmalar değerlendirildiğinde, öğretmenlerle gerçekleştirilen çalışmaların çok az olduğu dikkat çekmektedir. Oysaki gerçekleştirilecek çalışmalarda öğretmenlerin matematik okuryazarlığına odaklanılması önemlidir. Çünkü bu süreç öğretmenden öğrenciye devam eden bir etkileşim olarak ifade edilebilir.

Matematik eğitimi alanında matematik okuryazarlığı üzerine yapılan lisansüstü tezlerin tercih ettikleri veri toplama araçları incelendiğinde en çok anket/ölçek ve testlerin veri toplama aracı olarak tercih edildiği görülmüştür. Bu durum yapılan çalışmaların daha çok deneysel çalışmalar olmasından kaynaklanabilir. Bunları sırayla mülakat/görüşme ve dokümanların takip ettiği tespit edilmiştir. Test olarak en çok başarı testlerinin kullanıldığı saptanırken bazı çalışmalarda test, ölçek ve görüşme bir arada kullanılmıştır. Buna karşın en az tercih edilen veri toplama araçlarının açık uçlu sorular, video kaydı ve gözlem olduğu belirlenmiştir.

Matematik okuryazarlık düzeylerini artıracak önemli etkenlerden birinin öğretmen ve öğretmen adayları olduğu düşünülürse, lisans öğrencilerinin (öğretmen adaylarının) ve öğretmenlerin matematik okuryazarlık düzeylerinin tespit edilmesi ve artırılması büyük önem taşımaktadır. Bu sebeple lisans düzeyinde ve öğretmenlerle matematik okuryazarlık çalışmalarının sayısının artırılması gerekmektedir.

Araştırmamızda incelenen tezlere bakıldığında matematik okuryazarlık ile ilkokul düzeyinde çalışmaya rastlanılmamıştır. PISA sınavlarına girecek olan öğrencilerin okuryazarlık temelleri ilkokul düzeyinde atıldığından ilkokul öğrencileri ile matematik okuryazarlığı çalışmaları yapılabilir.

Ayrıca PISA sınav sonuçlarına göre ülkemiz matematik okuryazarlı̆̆ında ortalamanın altında bir başarı göstermektedir. PISA 2018'e katılan 79 ülkenin matematik alanındaki ortalama puanları 325 ile 591 arasında değişmektedir. Katılımcı 79 ülkenin matematik alanındaki ortalama puanı 459, 37 OECD ülkesinin matematik alanındaki ortalama puanı ise 489 olarak hesaplanmış olup Türkiye 454 ortalama puanla, 79 ülke arasında matematik alanında 42. sırada, 37 OECD ülkesi arasında ise 33. sırada yer almaktadır (MEB, 2019). Bu durumun düzelmesi için matematik okuryazarlık düzeyini yükseltebilecek yöntem ve tekniklerin bulunması ve uygulanmasına yönelik nitel çalışmaların sayısı artırılabilir.

\section{Kaynaklar}

Altun, M. (2020). Matematik Okuryazarlı̆̆ El Kitabı: Yeni Nesil Soru Yazma ve Öğretim Düzenleme

Teknikleri. Bursa: Aktüel Alfa Akademi Yayıncılık.

Çepni, S. (2016). PISA ve TIMSS Mantığını ve Sorularını Anlama. Ankara: Pegem Akademi.

Çalık, M. ve Sözbilir, M.(2014). İçerik Analizinin Parametreleri. Eğitim ve Bilim, 39 (174), 33-38. 
De Lange, J. (2003). Mathematics for literacy. B. L. Madison ve L. A. Steen (Eds.), Quantitative literacy: Why numeracy matters for schools and colleges. Princeton, NJ: The National Council on Education and the Disciplines, 75-89.

Dinçer, S. (2018). Content Analysis in for Educational Science Research: Meta-Analysis, MetaSynthesis, and Descriptive Content Analysis. Bartın Üniversitesi Eğitim Fakültesi Dergisi, 7(1), 176190.

Doyle, K. (2007). The Teacher, The Tasks: Their Role in Students? Mathematical Literacy. In Watson, Janeand Beswick, Kim, Eds. Proceedings 30th annual conference of the Mathematics Education Research Group of Australasia - Mathematics: Essential Research, Essential Practice, 246-254.

Durlak, J.A. (1995), Reading and understanding multivariate statistics. Washington, DC: American Psychological Association.

EARGED, (2005). PISA 2003 Projesi Ulusal Nihai Rapor. Ankara: MEB-Eğitimi Araștırma ve Geliştirme Dairesi Başkanlı̆̆ı.

Edge, D. L. (2009). Math Literacy: The Relationship of Algebra, Gender, Ethnicity, Socioeconomic Status, and Avid Enrollment With High School Math Course Completion and College Readiness. University of North Texas. Erişimadresi:https://search.proquest.com/openview/0a1145a64a709990201873a68e6fd310/1? pq-origsite $=$ gscholar $\& \mathrm{cbl}=18750 \&$ diss $=\mathrm{y}$.

Fırat, İ. (2019). Türkiye'de Matematik Okuryazarlı İle İlgili 2020 Yılına Kadar Yapılan Çalışmaların Doküman Analizi Yöntemiyle Incelenmesi. (Yüksek Lisans Tezi). YÖK Tez veri tabanından erişildi (Tez no:620110).

Graven, M. ve Venkatakrishnan, H. (2006). Emerging successes and tensions in the implementation of Mathematical Literacy. Learning and Teaching Mathematics, 4, 5-9.

Oğuz Haçat, S. ve Demir, F.B. (2018). Sosyal Bilgiler Eğitimi Üzerine Yapılan Doktora Tezlerinin Değerlendirilmesi (2002-2018). Avrasya Uluslararası Araştırmalar Dergisi, 6(15) , 948-973.

Oğuz Hacat, S. ve Demir, F.B.(2019). Eğitim Alanında Okuryazarlık Üzerine Yapılan Lisansüstü Tezlerin Analizi. Anadolu Kültürel Araştırmalar Dergisi, 3(2), 116-145.

Hardianti, S. ve Zulkardi, Z. (2019). Students Mathematical Literacy Abilities in Solving PISA Typemath Problem With LRT Context. Journal Of Physics: Conference Series, 1315 (1), 1-7.

İskenderoğlu, T. A. ve Baki, A. (2011). İlköğretim 8. Sınıf Matematik Ders Kitabındaki Soruların PISA Matematik Yeterlik Düzeylerine Göre Sınıflandırılması. Eğitim ve Bilim, 36(161), 287-301.

Julie, C. (2006). Teachers' Preferred contexts for Mathematical Literacy As Possible Initiators For Mathematics For Action. African Journal of Research in Mathematics, Science and Technology Education, 10 (2), 49-58.

Kabael, T. (2018). Matematik Okuryazarlığı ve PISA. Ankara: Anı Yayıncılık.

Kaiser, G. ve Willander, T. (2005). Development Of Mathematical Literacy: Results Of An Empirical Study. Teaching Mathematics and its Applications, 24 (2), 48-60.

Kilpatrick, J. (2001). Understanding Mathematical Literacy: The Contribution Of Research. Educational Studies in Mathematics, 47 (1), 101-116.

Köysüren, M. ve Devrim, Ü. (2018). Matematik Öğretiminde Teknoloji Kullanımının 6. Sınıf Öğrencilerinin Matematik Okuryazarlığına Etkisi. Necatibey Eğitim Fakültesi Elektronik Fen ve Matematik Eğitimi Dergisi, 12 (2), 81-101.

Lutzer, C. V. (2005). Fostering Mathematical Literacy. Problems. Resources and Issues in Mathematics Undergraduate Studies, 15 (1), 1-6. 
MEB. (2009). İlköğretim Matematik Dersi 6-8 Öğretim Programı. Ankara: Milli Eğitim Bakanlığı Talim ve Terbiye Başkanlığı.

MEB. (2016). PISA 2015 Nihai Raporu. Ankara: Milli Eğitim Bakanlığı.

Mullen, J. (2009). Enhancing mathematical literacy. (Master's thesis). School of Arts and Sciences St. John Fisher College.

NCTM. (1989). Curriculum and Evaluation standards for school mathematics. Reston, VA: The Council.

Ojose, B. (2011). Mathematics literacy: Are we able to Put The Mathematics We Learning to Everyday Use. Journal of Mathematics education, 4 (1), 89-100.

Özgen, K. ve Bindak, R. (2008). Matematik Okuryazarlı̆̆ı Öz-Yeterlik Ölçeğinin Geliştirilmesi. Kastamonu Eğitim Dergisi, 16 (2), 517-528.

Prabawati, M. ve Herman, T. (2019). Mathematical Literacy Skills Students of The Junior High School in Term of Gender Differences. Journal of Physics: Conference Series, 1315 (1),1-7.

Rifandi, R., Puspita, V. ve Mulyati, A. (2019). The Validity of Problem Solving Based Teaching Material on Mathematical Literacy in The Meintegrated Learning. Journal Of Physics: Conference Series. 1317 (1).

Romberg, T. A. (2001). Mathematical literacy: What Does It Mean For School Mathematics. Wisconsin School News, 10, 5-8.

Sanjaya, F., Putu, W. D., Julie, H., Anggoro, A. Y. ve Rudhito, M. A. (2019). The Mathematics Education Department Students' Ability in Mathematical Literacy For Uncertainty Problems on PISA Adaptation Test. Journal Of Physics: Conference Series, 1366 (1), 1-8.

Solomon, Y. (2008). Mathematical Literacy: Developing Identities of inclusion. Routledge.

Umbara, U. ve Suryadi, D. (2019). Re-Interpretation of Mathematical Literacy Based on the Teacher's Perspective. International Journal of Instruction, 12(4), 789-806.

Taşkın, E., Ezentaş, R. ve Altun, M. (2018). Altıncı Sınıf Öğrencilerine Verilen Matematik Okuryazarlığı Eğitiminin Öğrencilerin Matematik Okuryazarlı̆̆ı Başarısına Etkisi. Kastamonu Eğitim Dergisi, 26 (6), 2069-2079.

Taufik, A. R., Pagiling, S. L. ve Dadi, O. (2019). The Process of Formulating in Mathematical Literacy in Solving PISA-Like problems Viewed From Cognitivestyle. IOP Conference Series: Earth And Environmental Science. 343 (1), 1-9.

Trapsilasiwi, D., Oktavianingtyas, E., Putri, I. W. S., Adawiyah, R., Albirri, E. R., Firmansyah, F. F. ve Andriani, Y. (2019). Mathematical Literacy of Male and Female Students in Solving PISA Problem by "Shapeand Space" Content. Journal of Physics: Conference Series. 1218 (1), 1-8.

Venkat, H. ve Graven, M. (2007). Insights into the implementation of Mathematical Literacy. African Journal of Research in Mathematics, Science and Technology Education, 11(2), 67-84.

Wolf, F. M. (1986). Meta-analysis: Quantitative methods for research synthesis. London: Sage Publications.

Yeniel, A. (2019). Seçmeli Matematik Uygulamaları Dersinin Öğrencilerin Matematik Okuryazarlık Düzeylerine ve Matematiğe Yönelik Tutumlarına Etkisi ve Öğretmen Görüşlerinin İncelenmesi (Yüksek Lisans Tezi). YÖK Tez veri tabanından erişildi (Tez no: 544029). 
“Türkiye'de 2008-2020 Yılları Arasında Matematik Okuryazarlı̆̆ı Üzerine Yapılan Tezlerin Analizi" başlıklı çalışmanın yazım sürecinde bilimsel, etik ve alıntı kurallarına uyulmuş; toplanan veriler üzerinde herhangi bir tahrifat yapılmamış, karşılaşılacak tüm etik ihlallerde "Sakarya University Journal of Education Dergisi ve Editörünün" hiçbir sorumluluğunun olmadığı, tüm sorumluluğun yazarlara ait olduğu ve çalışmanın herhangi başka bir akademik yayın ortamına değerlendirme için gönderilmemiş olduğu bu çalışmanın yazarları tarafından taahhüt edilmiştir. 